\title{
Plantation forests in Europe: challenges and opportunities
}

Peter Freer-Smith, Bart Muys, Michele Bozzano, Lars Drössler, Niall Farrelly,

Hervé Jactel, Jaana Korhonen, Gianfranco Minotta, Maria Nijnik, Christophe Orazio 


\section{Authors}

Peter Freer-Smith, University of California Davis, USA \& Forest Research, UK

Bart Muys, KU Leuven, Belgium

Michele Bozzano, European Forest Institute

Lars Drössler, Ilia State University, Georgia

Niall Farrelly, Teagasc, Ireland

Hervé Jactel, INRA, France

Jaana Korhonen, University of Helsinki, Finland

Gianfranco Minotta, University of Turin, Italy

Maria Nijnik, James Hutton Institute, UK

Christophe Orazio, European Forest Institute

\section{ACKNOWLEDGEMENTS}

The report benefited from the helpful comments from external reviewers, Arttu Malkamäki from the University of Helsinki and Margarida Tomé from the University of Lisbon. We wish to express our thanks for their insights and comments that helped to improve the report, and acknowledge that they are in no way responsible for any remaining errors.

This work and publication has been financed by EFI's Multi-Donor Trust Fund for Policy Support Facility, which is supported by the Governments of Austria, Czech Republic, Finland, Germany, Ireland, Italy, Lithuania, Norway, Spain and Sweden.

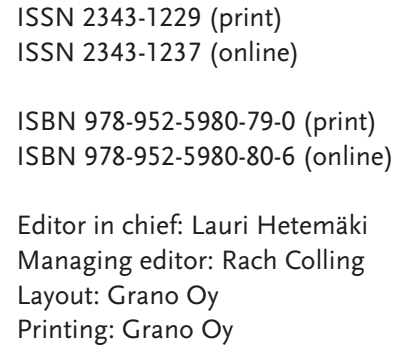

Disclaimer: The views expressed in this publication are those of the authors and do not necessarily represent those of the European Forest Institute, or of the funders.

Recommended citation: Freer-Smith, P., Muys, B., Bozzano,

M., Drössler, L., Farrelly, N., Jactel, H., Korhonen, J., Minotta,

G., Nijnik, M. and Orazio, C. 2019. Plantation forests in

Europe: challenges and opportunities. From Science to Policy 9.

European Forest Institute. https://doi.org/10.36333/fs09 


\section{Contents}

Executive summary . .4

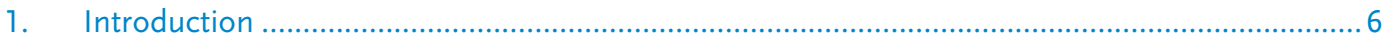

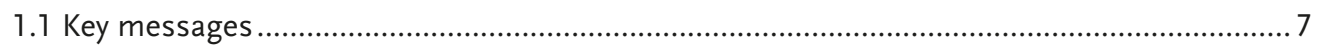

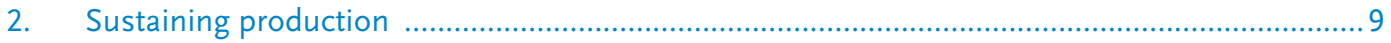

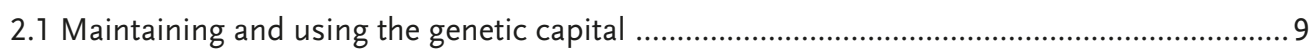

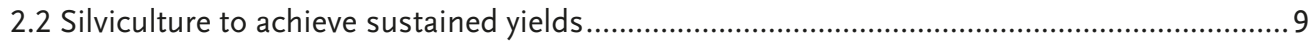

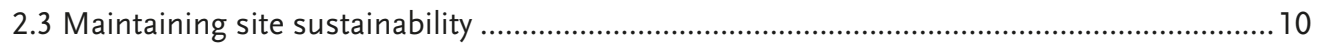

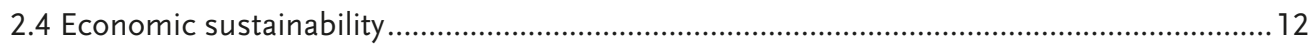

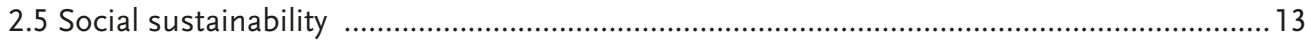

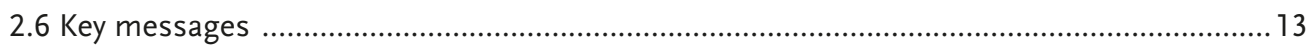

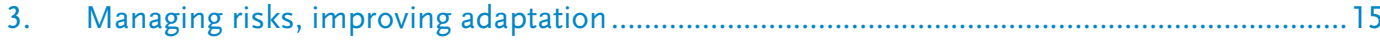

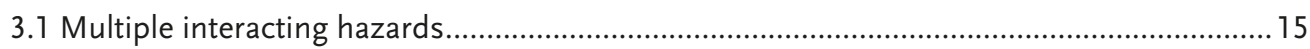

3.2 Reducing the susceptibility of plantation forests ............................................................ 15

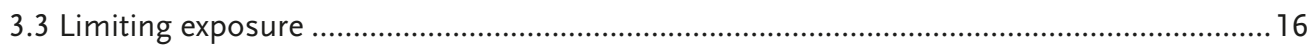

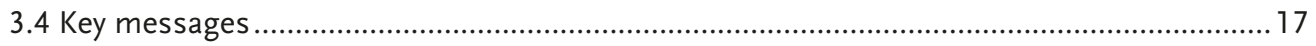

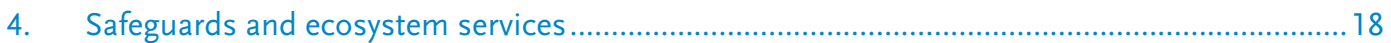

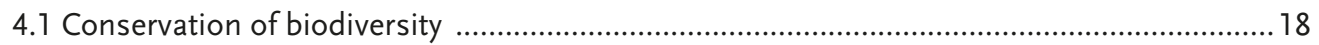

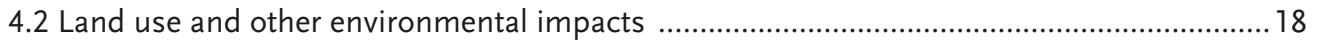

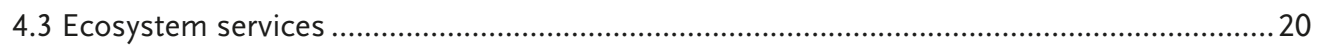

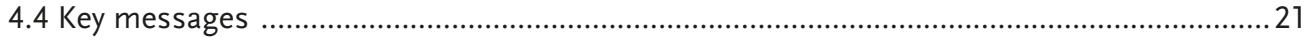

5. Social and governance aspects of plantations......................................................................2 22

5.1 Stakeholder and public perceptions of forest plantations ................................................ 22

5.2 Institutional settings, social innovation and governance structures ......................................2 24

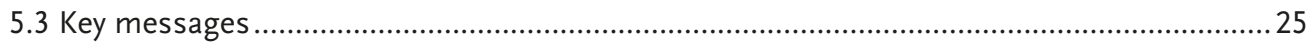

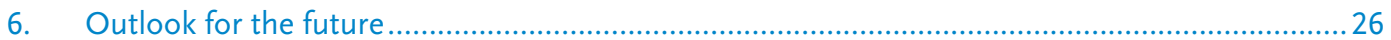

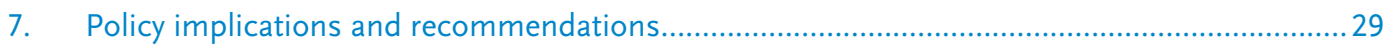

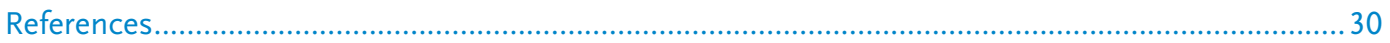

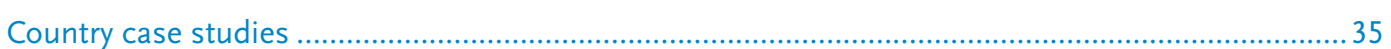

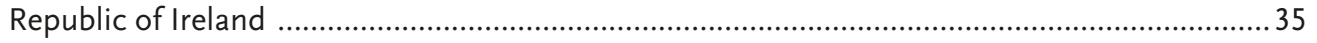

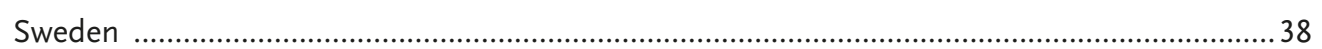

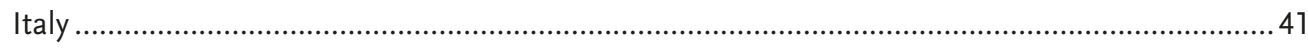

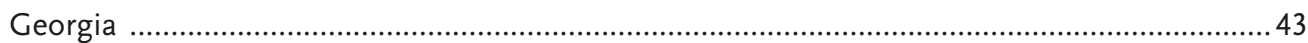

Appendix 1. Definition of plantation forests used in this study ......................................................45

Appendix 2. Site indicator values for analysis of land use impact.......................................................48

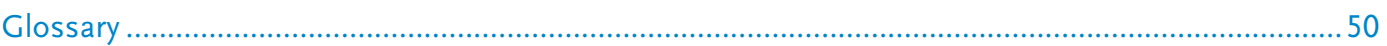




\section{EXECUTIVE SUMMARY}

$\mathrm{T}$ Sustainable Development Goals, Paris Climate Agreement, the Forest Europe process, and EU targets and policies set new demands for European forests. These include helping to mitigate climate change, providing goods and services, generating jobs and acting as a source of fuel and materials. The development of an innovative, sustainable bioeconomy is a key strategy, and in Europe forestry is expected to play a major part in supplying the feedstock and services required.

Plantation forests can play a key role in meeting these objectives. Globally forest area continues to decline, from 4.3 billion hectares to 4 billion hectares during the period 1990 to 2015 . However, over the same timeframe the area of planted forests has increased, and they now comprise $7 \%$ of the total global forest area and provide about $33 \%$ of the world's roundwood.

In Europe, the area of plantation forestry is also increasing, together with the proportion of roundwood and other services provided by plantation forests. There is new evidence that the sustainable management of plantations, particularly as part of a landscape-scale mosaic, has strong potential to deliver against Europe's emerging policy priorities.

The scientific evidence on how best to achieve these targets, while achieving multifunctionality and maximizing the synergies between ecosystem services is key to the success of future forestry programmes. We therefore draw on recently published research and four case studies (Ireland, Sweden, Italy and Georgia), to set out the major policy implications.

\section{A new equilibrium}

The need for healthy and productive forests which also deliver the conservation of biodiversity and forest protection, has led to sustainable forest management (SFM) becoming the basis of most forestry strategies.
However, "plantation forests" have often been viewed negatively, for example, from the monoculture and biodiversity perspective. In the past, poor tree species selection, poor silviculture and failure to consider social issues (especially local communities) in afforestation schemes have sometimes created problems, and led to the discrediting of plantation forestry. However, plantation forests do not need to create problems if planted and managed in ways that take into account environmental impacts the balance of different ecosystem services and the full range of stakeholder views.

In many regions, land-use mosaics incorporating forest plantations are highly effective in enhancing ecological integrity and in tackling climate and environmental challenges. Forest plantations are often a significant component of landscape-scale restoration, and can bring degraded land back into production and improve the provision of ecosystem services. If managed well, forest plantations have the potential to sustainably supply a substantial proportion of the goods and services required by society, and therefore allow other forest areas to be managed for conservation and protection objectives.

The challenges are to design and manage plantations in ways which can cope with climate change, limit the threat from pests and pathogens, and achieve a balance of ecosystem services at the landscape or ecosystem scale.

Plantation forestry is also increasingly changing from large-scale investments in monocultures to small or medium-scale investments in which local households and communities are owners or co-owners as well as being employed in forestry and wood processing. 


\section{Policy recommendations}

- In Europe plantation forestry already plays a significant role in meeting environmental, economic and climate needs and further investments could enhance these contributions. Both research and policy measures are needed to support the establishment, ongoing sustainable management (SFM) and utilization of plantation forests.

- Research, guidance and regulation will continue to be required on the identification and production of forest reproductive materials for plantations. Species and the forest reproductive material itself should be selected not only for their production ability, but also for their ability to maintain or enhance the capacity of the forest to adapt to climate change.

- Owners and managers need to be aware that the risks related to plantation forests are currently increasing, due to growing abiotic, biotic and financial hazards. To mitigate risk, adaptation of forest management is necessary. The first option is to improve resistance by increasing plantation diversity. This could be done by combining complementary tree species within stands and using mosaics of different forest types at the landscape level. The second option is to reduce the exposed standing volume by intensifying thinning and harvesting regimes (e.g. by shortening rotation length).

- Sustained yield under climate change conditions requires resilient plantations and will become very difficult if average warming exceeds $2^{\circ} \mathrm{C}$. Resilience and sustainability can be achieved if regulations, incentives and practice guides specify science-based approaches to control standing stock and age class distribution in plantation forests with the use of species mixtures and other elements of risk management.

- To develop new sustainable and multifunctional plantation forests, economic policy measures focused on increasing the efficiency of timber supply should be complemented with well-targeted measures to preserve forests and conserve their biodiversity and landscape values.
- Large forest plantation schemes need to go hand in hand with a genetic conservation plan, addressing both tree genetic resources and fauna and flora in general. Land sharing and land sparing are equally valid conservation options that need consideration in a sustainable primary production landscape.

- Even intensively managed plantation forests have lower land use impact than agricultural systems. To some extent their intensification increases land use efficiency, but there is an optimum beyond which further intensification does not contribute much to increase productivity, while strongly harming the environment, including adjacent or downstream ecosystems.

- Even when focused on wood provision, plantations can also contribute strongly to regulatory and social ecosystem services, especially carbon sequestration and recreation. Forest plantations, and where suitable, agroforestry need to be integrated components of landscape scale restoration and management.

- Acknowledging the multiplicity of relevant stakeholders, the heterogeneity of their perceptions and the role of social innovations is important for designing and implementing sustainable forest policy measures.

- The methodologies for establishing and managing plantation forests are diverse and vary regionally across Europe. Thus there is no "one-size-fits all solution" to maximize socio-economic benefits and ongoing research support is required.

- For European forests to supply the circular biobased economy, research, policies and strategies need to be coordinated across the entire value chain from plantation establishment and management through to delivery of products and services. 


\section{Introduction}

The total global forest area decreased from 4.3 billion hectares to 4 billion hectares (3I\% of the global terrestrial area) from I990 to 2015 (FAO 20I5) Over the same period the area of planted forests increased from I68 to 278 million hectares and planted forests are now $7 \%$ of the total global forest area.

The essential role of forests in tackling many of the great challenges of our time has been increasingly recognized. For example, the Paris Climate Agreement and the UN Sustainable Development Goals - SDGs (UN 20I5) raise the importance of forests in helping to mitigate climate change, providing goods and services, generating jobs, sustaining incomes and acting as a source of food and fuel. The Convention on Biological Diversity (CDB) identifies forests as key to the conservation of biodiversity worldwide. The Forest Europe process and the EU Forest Strategy (European Commission 20I3) promote sustainable forest management to underpin several European priorities, including rural development, environmental, climate and biodiversity policies, the provision of ecosystem services, and the provision of sustainable growth and jobs. The EU has identified that the development of an innovative bioeconomy is a key strategy in decoupling human progress from resource use and environmental decline, and in Europe forestry is expected to play a major part in supplying the feedstock and services needed for sustainable bioeconomy pathways (Hetemäki et al. 20I7).

The EU has incorporated greenhouse gas (GHG) emissions and their removals by Land Use, Land use Change and Forestry (LULUCF) into its 2030 Climate and Energy Framework. Many countries have included large-scale forestry programmes (afforestation, reforestation and forest restoration) as part of their national climate change plans (UNFCCC Nationally Determined Contributions). There are also a number of multi-country forest creation and restoration initiatives e.g. the Bonn Challenge (2OI2) and The New York Declaration (20I4).

Considering the above context and objectives, planted forests can play a key role. Plantation forests have high yields and they provide about $33 \%$ of

I http://www.fao.org/forest-resources-assessment/past-assessments/fra-20I5/en/ the world's roundwood (Jurgensen et al. 20I4). In many regions, land-use mosaics incorporating forest plantations have been shown to be highly effective in enhancing ecological integrity and addressing climate and environmental challenges (e.g. Payn et al. 20I5). Forest plantations are often a significant component of landscape scale restoration and can bring degraded land back into production and improve the provision of ecosystem services. Furthermore, it has been estimated that, if managed well, forest plantations have the potential to sustainably supply a substantial proportion of the goods and services required by society, and thus to allow other forest areas to be managed for conservation and protection objectives (Silva et al. 20I8).

However, the role of plantation forests in providing ecosystem services is also controversial, and plantations of a single introduced tree species have been associated with problems of land tenure, community rights, decreased biodiversity and adverse environmental impacts (especially increased water use). Such problems were initially associated with countries in transition but some plantations (e.g. oil palm, eucalyptus, rubber and others) continue to be controversial, especially where single or very few non-native species are grown on a large scale in even-aged and regularly spaced plantations (e.g. FAO 2018). In Europe, plantations of single species, often pine, spruce or eucalyptus, occur where natural forests of mixed species were present prior to land conversion for agriculture, and some of these forests have also failed to provide acceptable social and environmental outcomes. The use of non-native species, as part of the range of species used in Europe, could bring a number of benefits, including better resilience to future climate ${ }^{2}$.

The need for healthy and productive forests which also deliver the conservation of biodiversity and forest protection, has led to sustainable forest management (SFM) becoming the basis of most forestry strategies. In the past, poor tree species selection, poor silviculture and failure to consider social issues (especially local communities) in afforestation schemes have sometimes created problems, and led

2 See the Non-native tree species for European forests project http://nnext.boku.ac.at 
to the discrediting of plantation forestry. In addition, the poor uptake of some afforestation and restoration schemes has resulted from low investor and landowner confidence in the long-term commitment of co-funders or from concerns over future price fluctuations. Experience has shown that government or international agency interventions are usually required to achieve the implementation of forestry programmes designed to meet society's needs.

The concept of active forest management has recently been introduced to distinguish between forests that have been planted and are now largely unmanaged from those which were planted and continue to be actively managed (FAO 20I8). This distinction is important in Europe where most forest land has been cleared at some point in history and only very little remains of what is considered old growth - natural forests. In addition, there is a significant proportion of European forest which was planted in the late I80os and the Igoos which is now under low-intensity management (Duncker et al. 20I2). These forests are of native and non-native species and were planted to supply timber and for soil protection. Currently there are also significant areas of former agricultural land which have been abandoned and are undergoing natural re-establishment to unmanaged woodland. Over the last Ioo years, forestry programmes have focused mainly on provisioning and conservation/biodiversity objectives. Adaptation to climate change, contributing to climate mitigation and to the circular bioeconomy are the emerging policy drivers. The scientific evidence on how best to achieve these objectives, on achieving multifunctionality and on maximizing the synergies between ecosystem services are key to the success of future forestry programmes.

In this report we focus on forest plantations in Europe. We define plantation forests as "forests predominantly composed of trees established through planting and/or deliberate seeding and which are being actively managed for provisioning services, climate regulation or both". Therefore, forests established only by natural regeneration, planted forests that are left unmanaged, and forests that are managed mainly for purposes other than provisioning services and climate regulation are not considered plantation forests in this study. This definition is based on that adopted by FAO in its ongoing Global Forest Resource Assessment, but we have modified the new FAO definition to better fit the European context (see Appendix I). The definition we use here is in agreement with the FAO definition in that both require forests to be planted and managed, but for the European context we do not wish to exclude managed stands which at maturity will resemble naturally regenerating forests. Even more importantly, we wish to include the use of more than two species, mixed age classes and irregular spacing (excluded by FAO). This is because we consider that these attributes could improve the resilience and delivery of services from plantations. Furthermore our objective here is to examine the idea that in Europe a balance of ecosystem services must be provided in forested landscapes, and that within these landscapes plantation forests have great potential to contribute provisioning and climate regulating services.

In this report we ask if plantation forestry is currently meeting its full potential to deliver European environmental and socio-economic policies, particularly targets on climate mitigation and for the developing bioeconomy. We have identified what science tells us about designing and managing forest plantations and their use to meet society's needs going forward, and addressed the following questions:

I. How best to achieve sustainable production and economic sustainability?

2. How to manage risk and improve adaptation?

3. How to safeguard the provision of a range of ecosystem services?

4. How to take into account the social aspects of forest plantations?

We have drawn on recently published research and, very importantly, also on four case studies. Our case studies were selected to illustrate some of the wide range of approaches and the different institutional frameworks that are in place to support the forestry and wood utilization sectors across Europe. Lastly, we have set out the major policy implications of the science which we have reviewed.

\subsection{Key messages}

- Globally forest area continues to decline, but plantation forest is increasing.

- The SDGs, Paris Climate Agreement, the Forest Europe process, the EU targets and policies set new demands for European forests. Plantation forests can help to meet these objectives. 
- Forest science and experience provide good understanding of the current challenges and opportunities for European forestry. A significant area of Europe's forests was planted, and is currently under low-intensity management and there are few forest management units where the full annual increment volume is harvested.

- "Plantation forests" have often been viewed negatively, for example, from the monoculture and biodiversity perspective. However, plantation forests do not need to create problems if planted and managed in ways that take into account environmental impacts, the balance of different ecosystem services and the full range of stakeholder views.
- However, there is new evidence that the sustainable management of plantations, particularly as part of a landscape-scale mosaic, has a strong potential to deliver against Europe's emerging policy priorities. We examine this potential in this report. 


\section{Sustaining production}

As plantation forests often have a dominant focus on wood production, we consider in this chapter the long-term sustainability of production from an ecological, economic and social sustainability viewpoint. Other ecosystem services and overall sustainability are considered in chapter 4 .

Trees are long-lived and slow growing and the final harvest of plantation forests usually occurs several years after establishment (Figure I). This implies the need for long-term thinking. Sustaining production over time will include conservation and improvement of the tree genetic resources (2.I), sustaining the yield levels of the plantation through optimized silvicultural interventions (2.2), and avoiding land degradation (2.3). But embedded in a quickly changing societal context, a successful plantation business will also need to ensure the economic (2.4) and social (2.5) aspects of sustainability.

\subsection{Maintaining and using the genetic capital}

Genetic diversity ensures that forest trees can survive, adapt and evolve under changing environmental conditions. Genetic diversity is also needed to maintain the vitality of forests and cope with pests and diseases. Plantation forests always involve the deployment of genetic material and it is important to understand what this means in practice.

Conservation of forest genetic resources in Europe is based on natural stands identified for their high phenotypic and genetic value. These natural stands harbour sufficient genetic diversity to allow adaptation to a changing environment. As a whole, they ensure that the adaptive capacity of the conserved forest tree species is maintained, and in most cases, individual stands serve as a source of forest reproductive material for breeding and planting. Central to the coordination of conservation and sustainable use of forest genetic resources in Europe is the European Forest Genetic Resources Programme (EUFORGEN), established in 1994 within the framework of Forest Europe. ${ }^{3}$

Conventional breeding techniques, which are both deliberate crossings among carefully chosen parents and the selection of seed from better-performing

3 See www.euforgen.org individual trees, remain the primary source of improved forest reproductive material (Konnert et al. 20I5). The primary breeding targets until the last decade were the volume and shape of the trees produced, the adaptive capacity being secured by having sufficient genetic diversity. Nowadays with global change, the challenge for the breeding organization is to provide genetic material adapted to actual and predicted future climates, as well as resistant against pests and diseases - not only those that threaten today but also those that could become a threat as conditions continue to change.

Crucially, plantation forests need to use adapted and diverse seed. Success will require forest reproductive material that is already suited to local site conditions and that has the diversity to enable the population to be self-sustaining in the decades ahead by allowing it to adapt to changing environmental conditions. It may take time and effort to identify the most suitable plant material, and longer still to accumulate enough planting stock, but this time and effort represents an investment to achieve a sustainable plantation forest with potentially a longer lifetime and with better economic return. The disadvantages of using unsuitable plant material have been demonstrated at some sites in the past, for example introducing frost-sensitive provenances in inappropriate areas (Le Tacon et al. 1994). They very easily outweigh the effort required in getting well adapted and diverse material able to adapt to the future environment. Long-range planning is essential for plantation forests.

\subsection{Silviculture to achieve sustained yields}

The overall primary objective of plantation forestry is to optimize cost-efficient management systems to achieve wood production. Production targets are organized in forest management units (FMUs) which are geographically joined groups of forest stands, separated from each other with a sufficiently dense road network to facilitate management operations. Stands are the smallest units of management within which the same cultivation of trees or silviculture takes place.

Figure I shows the typical silvicultural cycles of major production systems selected from each of the 
four case studies of this report: Ireland, Sweden, Italy and Georgia, and for an extensively managed planted oak stand in Forêt de Soignes in Belgium. At the stand level, these systems typically show three intervention phases: stand establishment, stand tending and harvesting. Standard establishment practices consist of planting of qualified or tested forest reproductive material (see section 2.I) in rows or squares at optimized densities. This is often preceded by a more or less intensive form of site preparation, which may consist of cleaning up harvest residues and soil work.

Stand tending includes all interventions aimed at improving the growth and product quality of the stand. It mainly consists of vegetation management (non-crop species), thinning and pruning of the crop. Thinning and pruning are not needed in short rotation systems for biomass production, but become essential in rotation systems aiming to produce high quality materials like sawn timber or veneer (e.g. the poplar system described in Case I of Figure I).

Harvesting is commonly by clear-cutting in which all trees of a forest stand are removed, but alternative systems exist (Figure I). The advantages of clearcutting are mainly techno-economical, including the potential for mechanization, the avoidance of felling damage to remaining trees and the delivery of large homogeneous lots of wood product. The disadvantages of clearcutting are usually mainly ecological (see 4.2). The size of clearcut areas can vary enormously, and for every circumstance, an optimum size of clear cut can be determined by considering the trade-offs between the pros and cons outlined above. In a sustainable plantation the harvested trees will be replaced with a new generation of young trees, and the production cycle is closed.

In conventional forestry each stand is usually made up of trees which are all of the same age, but the stands are of different ages to ensure a steady supply of wood at a harvestable age over time. This means that there is normally a roughly equal area of stands at each age in the total FMU. A normal forest ensures a constant standing stock over time but also delivers a constant flow of harvested product. This approach is an important asset for carbon (C) sequestration and climate mitigation as well (Nabuurs et al. 20I8).

Recently forest plantations show increasing stress, due to increased frequency of droughts and higher incidence of pests and diseases (Boyd et al. 2013). Under these conditions the advantages of monocultures and large-scale operations may get lost because of the, sometimes unacceptable, risks of damage or collapse. Production approaches with more species mixtures, layered stand structure and higher degrees of naturalness like permanent polycyclic plantations or retention approaches (Lindenmayer et al. 20I2) have shown advantages in terms of resistance and resilience to these risks and disturbances, but may also imply impracticalities, in terms of more complicated tending, harvesting and grading. Plantation forests are therefore in need of a new equilibrium which will rely more on the demonstrated diversity insurance effects (see chapter 3), while continuing to deliver the expected products in a profitable way.

\subsection{Maintaining site sustainability}

Successful plantation forests are those that show a perfect match between the prevailing site conditions in terms of climate and soil and the site requirements of the selected tree species. If achieved, a good match of trees and site will ensure high productivity, low sensitivity for pests and diseases and low risk of abiotic disturbances. This site matching is based on science and empirical observations, and thus for plantation forestry in new areas or with new species there is a need to establish species and provenance trials, and to monitor them over a long time and in a large set of climates as a continuous reference. As a result of global change, new mixed species trials are now needed in which the effects of silvicultural treatment on growth, yield stability and species interactions can be tested.

Sites can also be further improved to increase wood production. When deciding on the intensity of these interventions the law of diminishing returns should be applied in order to maximize economic return and avoid negative environmental impacts. Improvement can include soil and water management, e.g. fertilizer application, irrigation or drainage, fencing to exclude grazing by deer etc. and forest protection measures, e.g. mechanical or chemical vegetation management of the young stands, and biocide application against insect or fungal attacks. In European plantation forests the use of fertilization in irrigation water and biocide (pesticides and herbicides) use are very limited or nonexistent, either for cost or environmental reasons. This has placed a 

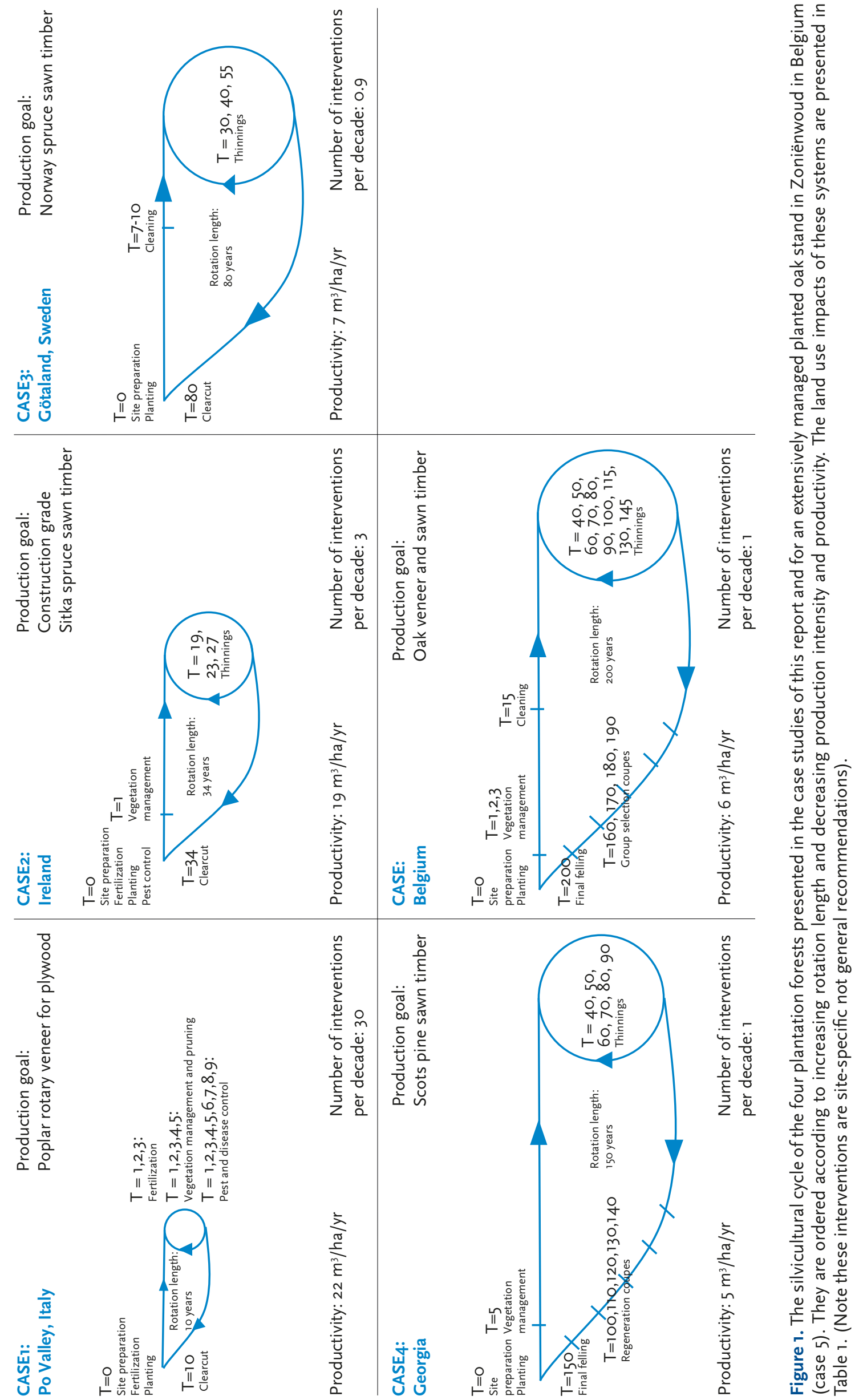
priority on the optimization of plantation productivity by genetic improvement (see 2.I).

The long-term conservation of the soil and water capital of a plantation will be ensured by all measures avoiding organic matter, nutrient and sediment loss in thinnings and final harvest through oxidation, leaching, surface runoff and erosion. Especially in areas with steep slopes and sensitive soils, this requires limitations to the area of a clear cut, to the intensity of soil preparation, and to the amount of harvest residues to be taken for bioenergy use, the mechanical intervention seasons, and the intensity of soil preparation for crop re-establishment. Similarly, sensitive methods for the construction and maintenance of roads, and good practice guidelines for harvesting and wood transport are indispensable (Cristan et al. 2016).

Among forestry systems, plantation forests are considered intensive high input systems, but compared to agricultural systems they are only medium input. Wood also has a much lower nutritional content than most agricultural products making wood generally less attractive to pests, pathogens and grazing animals, and also meaning that lower nutrient export occurs at harvest. Thus, tree production has an intrinsically lower need for fertilizers and biocides than food crops, and requirements can be further reduced by genetic improvement, low impact harvesting leaving nutrient-rich harvest residues on site, and precision forestry.

\subsection{Economic sustainability}

As a result of market imperfections and factors specific to forestry, achieving economic sustainability for plantation forestry requires a different approach to that conventionally adopted in considering the use of natural resources (Nijnik 2004). In forestry the role of government is important in balancing economic, social and environmental objectives, in regulating tenure and in the management, financing and production of public goods. Thus policies to increase timber supply need to be complemented with well-targeted measures to preserve forests and conserve their biodiversity and landscape values. The extent to which such measures are in place varies across Europe (see case studies). Furthermore, changes of forest product prices due to changing market conditions or policy measures, such as the price for sequestered carbon, will have an impact on the economic sustainability of forestry. A highly relevant example of this has been the impact of subsidies for woody biomass use in energy generation on the wood production and utilization sectors.

Economic sustainability can be considered to be achieved if the returns from forestry exceed the costs of the forest operations. However, normally the returns from forestry would also need to exceed those from any alternative land use. Therefore, enlarging the efficiency of plantation forests, e.g. by optimizing timber rotation ages, can be a way forward. According to Faustmann (1849), the optimal rotation is when the marginal benefits of postponing harvesting are equal to the marginal costs of its delay. A way towards sustainability then largely depends on how well the markets are functioning to deliver proper signals for achieving optimal allocations of resources.

However, profit maximization may not lead to the highest social benefits. While multiple values of plantations are important, the amenity values are usually not captured by the owners, and inefficiently short rotations are thus promoted. Sustainability criteria and indicators are better defined through an open debate in some sort of stakeholder forum (see chapter 5). To take these broader issues into account, the Faustmann model was extended into maximisation of the net present value of the revenue flows from both timber and non-timber forest outputs (Hartman I976). The model can also be further extended by incorporating the forest's ability to accumulate carbon. In most cases the rotation ages of plantations used for multiple purposes are longer, although see discussion in section 3 on the way in which rotation length can affect risk.

Because plantation forests provide benefits far away into the future, discounting in economic considerations is crucial. Discounting in calculations of economic value refers to the use of a discount rate, reflecting the social value preference between having access to a product today rather than in a further future. However, there is a problem in the shortage of information on future effects of current activities. Uncertainties relate to prospective demand and supply of timber, tenure/property rights on land and forest resources, and services (including on terrestrial carbon sequestered) and institutional settings, and innovations, etc. (Nijnik and Pajot 20I4). Economic risks may also be connected to future technological, economic, environmental, and social dimensions of forestry and wider land use systems. 
The environmental value of forest products replacing carbon-intensive fossil fuels and materials and enhancing the circularity of the economy may be considerable, but difficult to assess and to predict.

Looking forward, plantation forests will need to continue to provide conventional forest products such as pulp, packaging paper and sawnwood and to supply the newly emerging sectors relying on a wide range of bioproducts, such as raw materials for textiles, bioplastics, fine chemicals, biofuels and engineered wood products (e.g. cross-laminated timber). However, changes in policies, markets and social norms (often linked to stakeholder attitudes, perceptions and behaviours) contribute to the importance of risk management where plantation forestry is concerned.

For sustainability in plantation forestry to be operational it has to be defined by criteria and indicators. Forest rent is a useful economic indicator. The proportion of rent captured by the government provides evidence on whether the revenue from forestry is sustainable. This enables decision-makers to take measures to enhance economic sustainability further. However, when markets and public institutions fail and forest resources remain undervalued, rent-seeking and the shadow economy may be a problem, reducing the tax base of the state (Nijnik 2004). Moreover, the income and employment generated by the value chain, that is in the wood processing sector, is important.

\subsection{Social sustainability}

Social considerations are of primary importance as the demand for ecosystem services from plantation forests increases and diversifies. For plantation forests to gain social legitimacy they need to be established and managed in ways that enable engagement with the demands of broader society. This needs to go beyond "creating acceptance" of timber production from plantations. Forest certification schemes may be effective for this, as they are intended to steer consumer behaviour to support environmentally appropriate, socially beneficial, and economically viable production by providing information on the sustainability of forest management or on the entire chain-of-custody from forest to the sale point (van der Ven and Cashore 2018).

Plantation forests are needed to meet the growing demand for raw materials in a fossil energy-free economy. The bioeconomy is therefore expected to create income generation from both conventional wood processing and newer utilization chains. Plantation forests generate employment across the whole forest sector - both the production of materials and the subsequent processing. Sustainably managed plantations will also facilitate service-based employment, such as recreation and tourism. Furthermore, as afforestation projects have become a part of voluntary and mandatory carbon offset trading schemes, planting more trees is creating new short-term employment opportunities for diverse forest workers and experts.

Regional employment generated per hectare of plantation forest might be less than that provided by competing land use types (e.g. when the land is used by agricultural enterprises), but forest plantations create jobs across the whole processing and utilization chain and any jobs generated from use of low productivity or abandoned land for e.g. carbon offsetting or other ecosystem services would be supplementary (Schirmer and Bull 20I4). Plantations are usually located outside of cities and they can enhance rural areas. However, efforts to establish and manage plantations may suffer from rural-urban migration as young people especially are rapidly urbanizing.

Incorporating diverse knowledge in decision-making along the entire value-chain can help mitigate risks and increase the resiliency of plantation management and plantation forest-based businesses. Women represent a minority in the working population of the forest-related production sectors (Lawrence et al. 20I7). This proportion has remained relatively stable between I990 and 20Io but may be improved across the whole value chain. Low workforce race and gender diversity are also key concerns, and social inclusivity needs to be addressed in education, recruitment and training in parallel with increasing plantation area. Equal pay schemes among the workforce across different geographical locations where plantation forests exist are also a concern for those who work in plantations.

\subsection{Key messages}

- The species and the forest reproductive material used in plantation forests should be selected not only for their production ability, but also for their ability to maintain or enhance the capacity of the forest to adapt to climate change. 
- Sustained yield under climate change conditions requires resilient plantations. These can be achieved by adopting innovative approaches to control standing stock and age class distribution with the use of mixtures and other elements of risk management (see chapter 3).

- Sustainable plantation management involves science-based interventions designed to optimize stand nutrient use efficiency and to conserve soil and water resources. Forest plantations need less fertilizer and biocide application than food crops and these inputs can be reduced further by genetic improvement, low impact harvesting and precision forestry.

- The economic sustainability of plantation forests largely depends on how well the markets are functioning to deliver proper signals for achieving optimal allocations of resources. The role of governments to regulate the tenure, management, financing and production of public goods, remains necessary under the conditions of a highly advanced market economy. Economic sustainability depends also on the consumer acceptance of plantation-based products and services.
- Policymakers can enhance social sustainability by promoting the education, recruitment and training of a diverse workforce. Securing the health and safety of workers should be complemented with ensuring equitable payment schemes and socially sustainable working conditions.

- The potential benefits of the bioeconomy in uncoupling socio-economic development from environmental degradation are substantial. Plantation forestry and its associated value chains have a major part to play in achieving a sustainable circular bioeconomy, if the risks are appropriately addressed. 


\section{Managing risks, improving adaptation}

Plantation forests are threatened by multiple risks that increase in frequency and magnitude because of climate and global changes. Risk can be defined as the combination of three components (Jactel et al. 20I2):

- the occurrence and severity of the hazard (e.g. storm, fire, pest) which is the cause of damage (e.g. tree mortality)

- the susceptibility of the system (here the plantation forest) to the hazard, which determines the amount of damage (e.g. how many dead trees)

- the exposure of the system, characterized by socio-economic value at stake exposed to damage (e.g. mainly wood loss).

Whereas hazards are essentially external forces independent of forest management, both susceptibility and exposure of forests to hazards often vary with the structure, composition and dynamics of forest stands, suggesting that risks might be mitigated by proper silvicultural operations (see Figure 2).

\subsection{Multiple interacting hazards}

The earth's climate is changing due to the increase in greenhouse gases produced by anthropogenic activities (IPCC 2019). Global warming has already induced drier conditions over the world with alarming effects on forest mortality (Hartmann et al. $2018)$. Fires were the cause of $16 \%$ of forest damage in Europe over the I950-2000 period (Schelhaas et al. 2003) and have greatly increased in magnitude recently (e.g. in Greece, Spain and Portugal) during very hot and dry summers. The boreal forests of Scandinavia are not any more spared from fire risk (Kelly et al. 20I3). Storm damage has already reached unprecedented levels and recent global climate models suggest that the frequency of windstorms will continue to increase in Europe (Martinez-Alvarado et al. 2018).

Plantation forests are also damaged by many pests and pathogens. This damage is likely to increase because global warming will result in shorter insect generation time and higher fecundity and survival, leading to increased range expansion and outbreaks of forest insects (Jactel et al. 20I9). A larger amount of breeding substrate following severe forest storms and drought will benefit bark beetles, resulting in large-scale conifer forest mortality (Schelhaas et al. 20I0). The exponential increase in the rate of establishment of new non-native forest pests and pathogens in Europe is continuing and this is due to the increase in the volume and speed of global trade (Brockerhoff and Liebhold 20I7), through many pathways involving wood products, packaging and plants for planting.

These biotic and abiotic hazards are not acting independently but can cumulate their impacts (Jactel et al. 20I9). For example, root rot fungi make trees more vulnerable to storms, producing favourable conditions for bark beetle outbreaks. Multiple risks management should therefore become a key concept in modern plantation forestry.

\subsection{Reducing the susceptibility of plantation forests}

Bad choices in silvicultural operations can aggravate the damage caused by hazards to forests. Conversely, adapting silviculture remains the best way to reduce the susceptibility of forest stands to the main threats (Jactel et al. 20I2). In plantation forests, the most crucial step concerns the choice of planting material. Forest managers have always known that the choice of plantation species should be adapted to local soil and climate conditions. Beyond this widespread wisdom, key messages have emerged from recent scientific work.

Tree monocultures, i.e. plantations of a single tree species, are generally more susceptible to fire, storm, pests and pathogens (Jactel et al. 20I7). Using the same species on large areas favours contagion and provides abundant and uniform fuel or feeding resources, while mixing different tree species can trigger host finding disruption and beneficial trophic (feeding) interactions like predation and symbiosis. To improve the resistance of plantation forests, it is thus advisable to intermix tree species with different levels of resistance and functional characteristics such as broadleaves and conifers. However, more research is needed to optimize the design of mixed species plantations to maximise benefits (higher productivity and resistance; Baeten et al. 2019) while minimizing costs (of planting and tending). The planting of multi-species hedgerows around a plantation may also serve as fire, wind and 
pest breaks (Dulaurent et al. 20I2). At a larger scale, increasing forest landscape heterogeneity using mosaics of plantations and remnants of natural forests should be considered as it can slow the spread of disturbances (wind, fire, pest).

The use of exotic tree species for plantation forests leads to the addition of two types of risks. First, exotic plantations are more susceptible to pests and diseases originating from their native range. Those pests and diseases generally benefit from being free of their natural enemies (e.g. predators and parasitoids) which can be absent from the introduced range (Cincotta et al. 2009). This is the case in eucalyptus plantations heavily defoliated by the snout weevil Gonipterus platensis, originating from Australia (Branco et al. 20I6). Similarly, the use of radiata pine as a plantation species in the Basque country has now stopped due to the accumulation of too many diseases, i.e., red and brown needle blight, pitch canker, all of exotic origin. Second, exotic tree species introduced in Europe are not spared by pests native to Europe, as a total of 590 host shifts of European insects to exotic trees have been recorded (Branco et al. 20I5).

It is important to differentiate the use of exotic tree species from the transfer of provenances of European tree species to the northern part of their natural range. This process of "assisted migration" is proposed to accelerate the adaptation of planted tree species to warmer conditions.

Although some scientists continue to call for genetically modified trees to resist insect pests, especially exotic ones, hopes placed in the genetic improvement of trees for resistance have not kept their promises. We are not aware of any successful tree breeding programme to improve resistance to fire or wind damage. For forest pest insects, the only operational programme is on white pine weevil resistance of Pinus strobus in Canada (Sniezko and Koch 20I7). The main reasons for the difficulty in breeding more resistant varieties is that resistance has to be sufficiently heritable, not negatively correlated with tree growth or resistance to other pests, and sustainable. The generation time of insects is in the magnitude of the year whereas the lifespan of trees is of hundreds of years, making insects likely to adapt quickly to new tree varieties. A promising application of tree breeding is for resistance to diseases, as shown in pines, eucalyptus and poplars (Sniezko and Koch 20I7) with short rotation length.
However, the durability of tree resistance to fungal pathogens relies on the maintenance of large genetic variability (e.g. using several clones with frequent replacement), in order to prevent pathogens from overcoming resistance.

Several silvicultural operations can reduce stand susceptibility (Jactel et al. 20I7). A crucial issue is to improve individual tree vigour, e.g. through ploughing, fertilizing, weed control and use of moderate tree density. This can accelerate initial sapling growth, which is key to avoid competition for water with understorey vegetation (drought resistance), avoid mammal grazing (herbivore resistance) and improve root anchorage (storm resistance). Later, individual tree vigour is mainly maintained through regular thinning, which has proved beneficial to resistance against bark beetles. However, forest plantations are more susceptible to wind damage just after severe thinning (Cucchi and Bert 2003). Thinning regimes should thus allow individual tree growth while maintaining a closed canopy to avoid storm damage and limit understorey vegetation, and also limiting the amount of fuel for forest fires. Salvage thinning is useful to remove decaying trees and in preventing outbreaks from developing into epidemics, as successfully demonstrated with the pine wilt disease (Kwon et al. 20II). Clear-cutting allows the removal of damaged or dying trees and replanting with better adapted trees. However, continuous cover forestry seems to improve plantation forest resistance to windstorms and fire by maintaining low understorey vegetation.

\subsection{Limiting exposure}

Compared to natural forests, plantations have higher costs of installation (e.g. planting seedlings of improved varieties vs. natural regeneration from wild seeds) and maintenance (e.g. thinning vs. no intervention). With a main objective to maximise wood production and quality, plantations also accumulate higher standing volume. Both the investment made and the value of products at stake are thus greater in plantation forests. Consequently, when exposed to hazards, they suffer damage of higher economic cost (Seidl and Rammer 20I7).

The first option to reduce the exposure of plantation forests is to increase their diversity. More diverse forests have a greater likelihood of containing at least some trees more resistant to various 


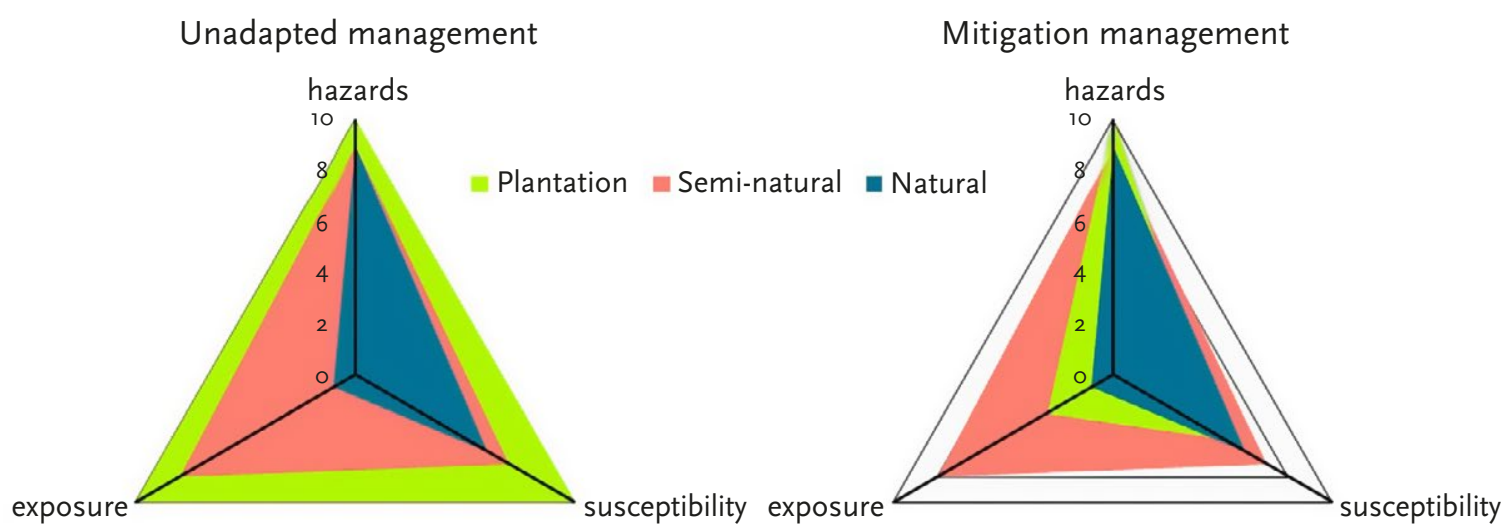

Figure $2 \mathrm{a}$ and $\mathrm{b}$. Schematic representation of biotic and abiotic risks associated with plantation, semi-natural and natural forests, with the relative importance of the three components of risks (hazards frequency or severity, forest stand susceptibility to hazards, and exposure to damage caused by hazards). Under current conventional management of plantation forests (a), with pure stands and intensive forestry practices, they are more at risk because, for a given level of hazard occurrence and severity, they are both more susceptible (as monocultures) and exposed (with large standing volume of good quality trees) than semi-natural or natural forests (made of a mix of species of different resistance, volume and quality). A mitigation management (b) of plantation forests, based on increased diversity of tree species, would spread the risk across different species of different resistance and market opportunities, thus reducing both susceptibility and exposure.

hazards, thus providing more opportunities to sustain wood production in the long term (the 'insurance hypothesis'). Because different tree species produce different wood-based products, any costs generated by damage to one species might be compensated by incomes from another tree species. The second option is to intensify harvesting. Reducing the growing stock by more intense or frequent harvests would decrease exposure e.g. standing volume at stake, as reviewed by Schelhaas et al. (2010) for the risks associated with fire and windstorms.

Forest plantations also carry large economic and financial risks because they grow slowly and thus provide most of their benefits far into the future. Throughout the entire silvicultural cycle (of several dozens of years) many factors may change, like demand and supply of forest resources and ecosystem services, market price, taxes and subsidies, social norms, which are all uncertainties for forest investors. The use of insurance then becomes a serious consideration in order to cover the cost of perils and an increasing number of insurance companies now offer specific policies for plantation forests.

\subsection{Key messages}

- Awareness: plantation forest managers should know that all risks are currently increasing, due to growing abiotic (drought, storms), biotic (native and exotic pests) and financial (market volatility) hazards.

- Adaptation: to mitigate risk, adaptation of forest plantation management is necessary. The first option is to improve resistance by increasing plantation diversity. This could be done by combining complementary tree species within complex stands, planting heterogeneous hedgerows around pure stands, or organizing a mosaic of different forest types at the landscape level. The second option is to reduce the exposed standing volume by intensifying thinning and harvesting regimes (e.g. by shortening rotation length).

- Insurance: because not all perils can be prevented or avoided, plantation managers should make greater use of insurance. The insurance might be ecologically based, via a larger portfolio of productive tree species, or financially based. 


\section{Safeguards and ecosystem services}

Plantations are managed systems and to maximize the provision of targeted wood products, management may need to be intense (see Appendix I). Intensive management defined by rotation length, amount of interventions, use of fertilizers and biocides, etc., may cause environmental changes, loss of biodiversity and decreased provision of other ecosystem services. Plantation management has many options to mitigate these impacts, through biodiversity conservation (4.I), caring about environmental safeguards (4.2), and maximizing win-wins with other ecosystem services (4.3).

\subsection{Conservation of biodiversity}

Plantations are mainly composed of one or a very few species. Nevertheless, they can play an important part in conserving biodiversity at the landscape level in two ways. First, although the plantation may have very low tree diversity, as an integral part of the landscape it creates a series of ecological niches or ecological corridors that are extremely valuable for many species of plants and animals. Second, even though they may be monocultures, sustainable plantations should contain and conserve enough genetic diversity to mitigate threats to their continued survival. As a result of environmental change this requires looking not only at what was adaptive in the past, but also at the future. How will a tree species adapt to future changes in climate and also to changing pest and disease regimes? How will different tree species interact as conditions change? These questions call for meaningful investment in mapping and characterization of genetic resources, to determine how genotypes and environment together determine phenotypic performance.

Genetic diversity is a foundation of the resilience of stands and landscapes. To protect that diversity, each country needs to regulate the number of mother trees in a seed orchard population and the number of clones that should be used in planting and replanting plantations on its territory. Only such regulations can prevent the existential risks that threaten genetically uniform plantations. A corollary of the need for diversity is to ensure that, as soon as a large afforestation scheme is being considered, a plan for genetic conservation is also in place. Conservation is vital to ensure that future generations of forest managers and tree breeders continue to have the opportunity to select the genetic material most appropriate to their needs and conditions. New Generation Plantations (Silva et al. 20I8), Forest Europe and the forestry certification schemes are all platforms which are bringing these ideas into practice.

Land sharing and land sparing offer two ways to promote conservation. Land sharing is the use of the same general area both to produce timber and to conserve genetic diversity. For example, an area of the plantation can be specifically designated to house a greater diversity of tree genotypes. A well-designed plantation can also offer protection to local flora and fauna, by reduced site preparation or reduced vegetation management. Land sparing separates production forest from the conservation areas in the landscape. If the plantation is very productive, that leaves more space for the less or not managed area that permits conservation. Both land sharing and land sparing options have their merits, and a mixture of both in a landscape can be recommended.

\subsection{Land use and other environmental impacts}

Life Cycle Assessment (LCA) is a common method to evaluate the environmental impact of production processes and products. In an LCA, based on an inventory of all inputs to the production process and all emissions caused by it, the contribution to the different impact categories is calculated for one functional unit of product. Typical functional units in the forestry sector are: a cubic metre of timber, a piece of furniture, a wooden house, a newspaper, or a pallet. Impact categories of relevance may be: water use, land use, eutrophication, acidification, global warming and human health. In a plantation, most impacts will increase with the level of intensification and the number of management interventions of the system.

In addition to timber production, plantation forests can have a positive environmental impact, i.e. provide an ecosystem service (see 4.3). For example, they may have a mitigating effect on global warming. Especially for plantations with longer rotations, providing products with long lifetimes and/or 
Table 1. Land use impact assessment of the case study plantations shown in Figure 1 and described in the country case studies, in comparison with extensive oak silviculture and intensive agricultural cropping in Belgium. This follows the LCA method of Peters et al. (2003).

LO/FU: the land occupation (LO) in hectares per year needed to produce a functional unit (FU) of $1 \mathrm{~m}^{3}$ of harvested wood, and is the inverse of the productivity.

LUI (land use impact): estimated deviances from the natural state (natural =0; maximum impact $=100$ ).

Overall LUI: calculated as the mean of the average vegetation, biodiversity, soil and water impacts, which in turn are means of several indicators (shown in Appendix 2).

LUI per FU (land use impact per functional unit): calculated by weighing the LO/FU with the overall LUI.

\begin{tabular}{|l|l|l|l|l|l|l|} 
& $\begin{array}{l}\text { Hybrid } \\
\text { poplar } \\
\text { Italy }\end{array}$ & $\begin{array}{l}\text { Sitka spruce } \\
\text { Ireland }\end{array}$ & $\begin{array}{l}\text { Norway } \\
\text { spruce } \\
\text { Sweden }\end{array}$ & $\begin{array}{l}\text { Scots pine } \\
\text { Georgia }\end{array}$ & $\begin{array}{l}\text { Oak } \\
\text { Belgium }\end{array}$ & $\begin{array}{l}\text { Cropland } \\
\text { Belgium }\end{array}$ \\
\hline LO/FU (in ha.year/m ${ }^{3}$ ) & 0.045 & 0.053 & 0.143 & 0.200 & 0.167 & n/a \\
\hline Average Vegetation Impact & 60 & 47 & 40 & 37 & 23 & 83 \\
\hline $\begin{array}{l}\text { Average Biodiversity } \\
\text { Impact }\end{array}$ & 60 & 39 & 10 & 8 & 4 & 73 \\
\hline Average Soil Impact & 13 & 15 & 14 & 6 & 6 & 40 \\
\hline Average Water Impact & 10 & 12.5 & 8 & 8 & 8 & 35 \\
\hline Overall LUI & 36 & 27 & 17 & 14 & 10 & 58 \\
\hline LUI per FU & 1.620 & 1.431 & 2.431 & 2.800 & 1.670 & n/a \\
\hline
\end{tabular}

which substitute for fossil energy and high carbon cost materials (e.g. cement and steel) means positive carbon balances are feasible. Another important example is the positive role of plantations for human health by filtering fine dust and providing a recreational space for city dwellers.

A major impact category for production processes which rely on land (agriculture, plantation forestry) is the land use impact, which measures how the activity affects the availability and quality of land. Given the difficulties of assessing land use impacts, there is no ISO standardized way to quantify this impact. The easiest way is to simply report the amount of land occupied to produce one functional unit, ex-

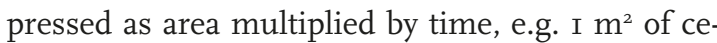
real land during I year to produce I bread. Peters et al. (2003) proposed to weigh this land use efficiency with a land use impact score, which measures the percentage loss of land quality in comparison with a natural unmanaged system on the same site. This overall land use impact score can be calculated using impact scores for quality loss of vegetation and biodiversity (impacts on ecosystem structure), and for soil and water impacts (impacts on ecosystem function). The indicators used to calculate impact scores for vegetation, biodiversity, soil and water are shown in Appendix 2.
In Table I the land use impact of the four case studies is compared with an extensively managed planted oak forest and an intensively managed agricultural crop system on the same soil in Belgium. What we learn from this assessment is the following:

- There is a broad range of plantation forests from relatively high land use impact to very low. The more intensively managed systems have obviously higher impact.

- In general, the impacts of plantations on soil and water are low. This can be explained by the relatively low frequency of intensity of soil disturbance, and the relatively strong control over water flows and microclimate. The indicators used do not penalize the increased water consumption by intensive plantations, but this can easily be considered by including off-site effects on aquatic systems to the impact calculation (Maes et al. 2009).

- The impacts of plantations on vegetation and biodiversity are often more important particularly where species monocultures, exotic species and short rotations are used. The risk of invasive spread of some exotic species in natural systems was not considered in this method, but can be an issue.

- Plantation forestry systems have a clearly lower land use impact than intensive agricultural 
systems. This is mainly explained by the lower amount of interventions leading to a higher degree of naturalness and rest.

- When expressing the impact per functional unit, the impact of intensive systems decreases, because they have higher productivity. This shows that land sharing and land sparing approaches are partly interchangeable: more intensive systems have more impact per unit of land, but are also more productive and thus occupy less land for the same amount of product. But there is an optimum beyond which further intensification does not contribute much to increase productivity, while strongly harming the environment, including adjacent or downstream ecosystems. The oak plantation with long rotations and low intensity management but relatively high productivity is an interesting case, because it is able to obtain low per hectare impact and low impact per functional unit simultaneously.

\subsection{Ecosystem services}

Although plantation forestry is essentially a land sparing strategy focusing on intensive wood production, and leaving it up to other areas to fulfil conservation goals, the current practice of plantation forests in many parts of the world leaves tremendous opportunities for conservation and other ecosystem services (ES).

The recognition of wider ES of forest plantations is a phenomenon of the post-industrial era. Its characteristic is a shift in emphasis from commodity to non-commodity outputs. Forests' ES may be: provisioning services including sawlogs, woody biomass for energy and non-timber forest products like mushrooms or game; regulating services of climate regulation, water purification and flood protection; and cultural services, including education, recreation, and aesthetic value (Millennium Ecosystem Assessment 2005) ${ }^{4}$. In the best case, plantation forests are important for all these services, which can contribute to their social and economic sustainability (Wolfslehner et al. 2019).

Woody biomass production from forest plantations interacts with other forest-related ecosystem services, sometimes negatively, sometimes positively. In economic and social/institutional terms

4 www.millenniumassessment.org/en/index.aspx plantation forestry must help society with climate change mitigation and adaptation by:

- responding to an increasing demand for renewable energy and material sources

- helping meet climate policy and EU targets on renewable/'cleaner' energy and materials

- assisting in delivering compliance with international agreements on tackling climate change through carbon sequestration in trees, soils and products

- supporting regional policies for rural employment and other development outcomes (Nijnik et al. 2016).

An ecosystem management approach provides a means to explore the multi-functionality of forest plantations through which synergies and trade-offs between forest ecosystem services can be tested and used with scenarios of biophysical and social changes (Nijnik and Miller 20I4). A growing necessity, however, arises in the translation of multifunctional objectives to forestry practices. This relates to answering the question of how to link global issues of sustainability to local level forestry (in understanding effects at different scales, and multi-level governance); how to achieve an efficient spatial integration of land use systems (e.g. forestry and the agricultural sector, e.g. at a landscape level), and how to link 'traditional' forestry (i.e. aiming for timber production) with other forestry-related interests (e.g. outdoor recreation or biodiversity conservation).

The generalised relationship in Figure 3 shows an increase in most ES as management intensity increases, up to a point, followed by a decline. For landscape and biodiversity, for example, the level of intensity at which the value of the ES declines may be quite low. High intensity forest management in association with wood energy production may well cause a decrease in value of non-market ecosystem services (EEA 2006). The actual shape and location of the impact curves will vary from one location to another. However, the point is that an increased intensity of woody biomass production is commonly associated with a diminution of multifunctional forest values. Sustainable intensification is the way forward to maximize the synergies between production, protection and mitigation (Silva et al. 20I8).

It is also important that different elements of the mix of forest ecosystem goods and services are influenced by markets or/and policies. When public money is limited, obtaining value for money from 


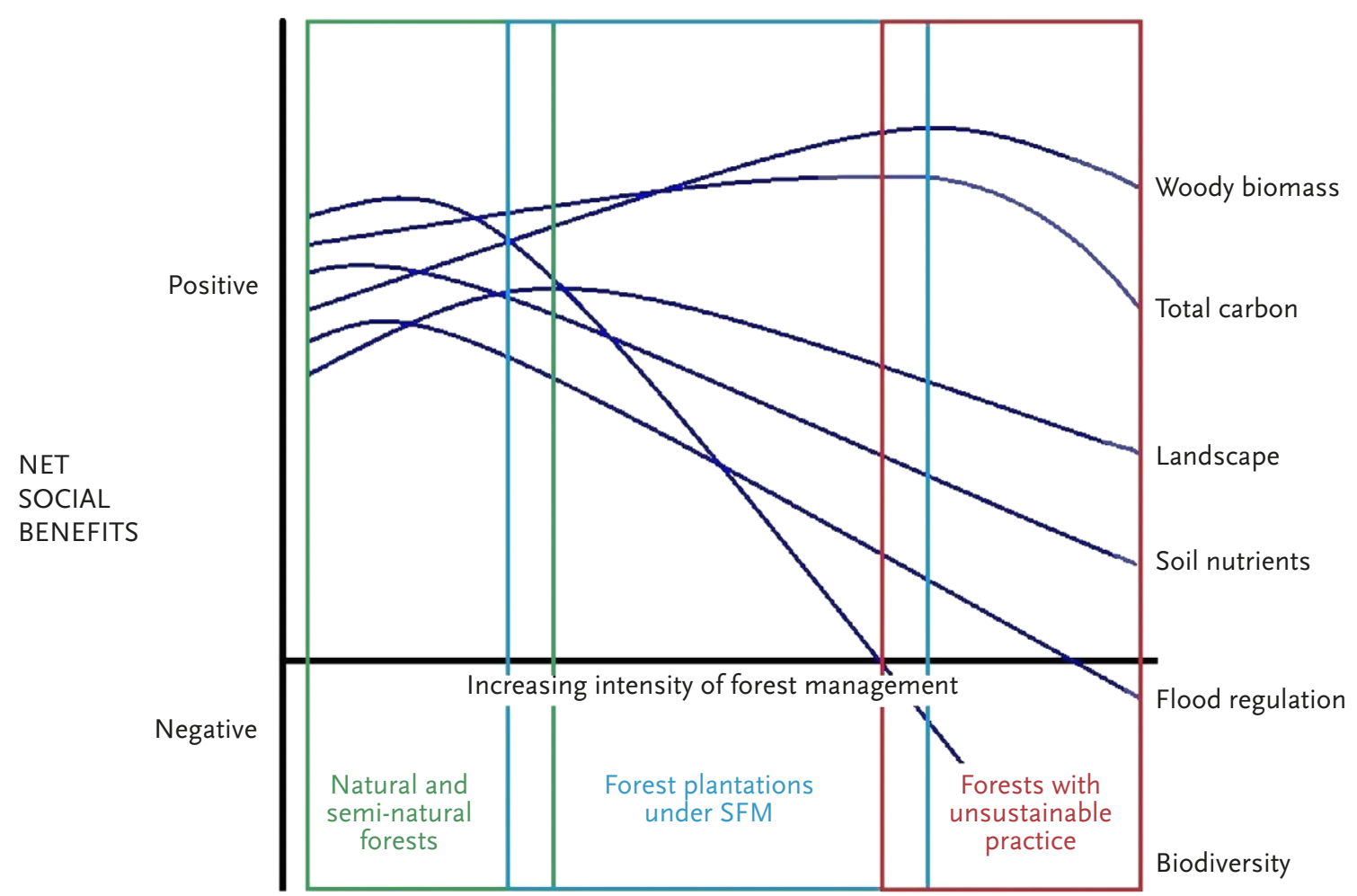

Figure 3. A theoretical model showing how management intensity may affect the delivery of ecosystem services for natural and semi-natural forests, plantation forests and forests with unsustainable practices. The shape of impact curves will vary with location, type of management and other factors. Management can be designed to achieve synergies and to minimize trade-offs in the delivery of ecosystem services (position along the $\mathrm{x}$ axis). Modified from Nijnik et al. 2016.

forests is essential. For example, voluntary carbon markets can offer opportunities to increase plantation forest incomes. However, some ecosystem services, whilst having high public good values, are usually not rewarded. Thus, monetary valuation may not be necessary or feasible for estimating all the positive and negative externalities of forest plantations. Non-market valuation techniques and the wider and more creative and effective engagement of stakeholders may enable practical decisions to be taken (Nijnik and Miller 20I7).

\subsection{Key messages}

- Large forest plantation schemes need to go hand in hand with a genetic conservation plan, addressing both tree genetic resources and fauna and flora in general.

- Land sharing and land sparing are equally valid conservation options that need consideration in a sustainable primary production landscape.
- Even intensively managed plantation forests have lower land use impact than agricultural systems. To some extent their intensification increases land use efficiency, but there is an optimum beyond which further intensification does not contribute much to increase productivity, while strongly harming the environment, including adjacent or downstream ecosystems.

- Plantations, even if focusing on wood provision, contribute strongly to regulating and social ecosystem services, especially carbon sequestration and recreation.

- We must exercise great caution in making generalisations: we must understand local social/institutional, economic and biophysical contexts and seek to factor the non-market goods and services of forest plantations more effectively into decision making through a more creative and effective process involving stakeholders. 


\section{Social and governance aspects of plantations}

In the past, controversy regarding plantation forests, and in some instances public protests, have resulted from lack of consultation and failure to understand and respond to public opinion. These outcomes can be avoided by understanding public perceptions and responding to the aspirations of people on the ground and along the value-chain. It is important to acknowledge and integrate public perceptions in relevant policies, and in the planning and management of plantation forests.

It is also important that different stakeholders are able to gain sufficient understanding of plantation forestry practices to formulate an informed opinion about forest plantations, and the synergies and trade-offs between the ecosystem services provided by them. There is variation regarding public perceptions across different countries, but also across different contexts and stakeholder groups.

Effective stakeholder engagement is likely to reduce the gaps between policies (and regulatory documents, e.g. various laws, rules, plans, regulations) and their implementation which are still observed in some places (examples can be found in our case studies). Going forward we also need to understand stakeholder and public perceptions and their role in innovative forest governance.

\subsection{Stakeholder and public perceptions of forest plantations}

Underlying values and emotions influence the perceptions that stakeholders have about different kinds of forests, forest ecosystem services and their uses. Different stakeholders (foresters and forest engineers, investors, forest owners, farmers and citizens et al.), have different interests and values and attribute different weight to the various aspects of forests and forest management. People are usually willing to adopt practices if they view them as socially acceptable, compatible with their beliefs and values, and with social norms. Social acceptance of plantation practices requires positive perceptions about the environmental and economic consequences of plantations along with a perceived societal need for them (Hemström et al. 20I4).

The establishment of new forest plantations and the associated increase of plantation forest area in Europe is likely to continue, as bioeconomy and climate strategies are implemented. However, the large divergence between past and sometimes current management practices in plantations (e.g. monocultures, clear-cutting) and the public perception of how sustainable management practices should be, has the potential to lead to opposition and serve as a source of conflicts (Ribe et al. 2013). Therefore, public and stakeholder perceptions of forest plantations and of the ecosystem services they provide must be well understood, even though they can be complex, diverse and historically determined (Nijnik et al. 20I0).

In Scotland, for example, heterogeneity of stakeholder perceptions regarding forest ecosystem services and their trade-offs were identified by Nijnik et al. (2०I6), as illustrated in Figure 4. In this study five attitudinal groups were identified. The findings indicate that:

- conservation of biodiversity receives the support of almost everyone

- people belonging to all 4 attitudinal groups, except group 4, consider the cultural and social role of forest plantations to be important

- provisioning services are considered important by all respondents, except those belonging to the attitudinal group 1

- people from two groups, $3 \& 5$, consider the use of forests for timber more important than everything else.

Results indicate that an increasing intensity of conservation measures may affect timber production, and vice versa. At one end of the spectrum, ecological approaches emphasise environmental protection, and at the other end, economic and climate change considerations promote production/carbon forestry. However, despite a wide heterogeneity of existing attitudes, all identified attitudinal groups support the necessity of multiplying wealth for people from forest plantations, while putting emphasis on stability and resilience of forest ecosystems. Also, Nijnik and Mather (2008) found for Scotland that afforestation can facilitate integration of aesthetic, ecological and socio-economic components in landscape management.

Importantly, people who hold rather opposing perceptions may change their views, for example once the initial benefits from plantations start 


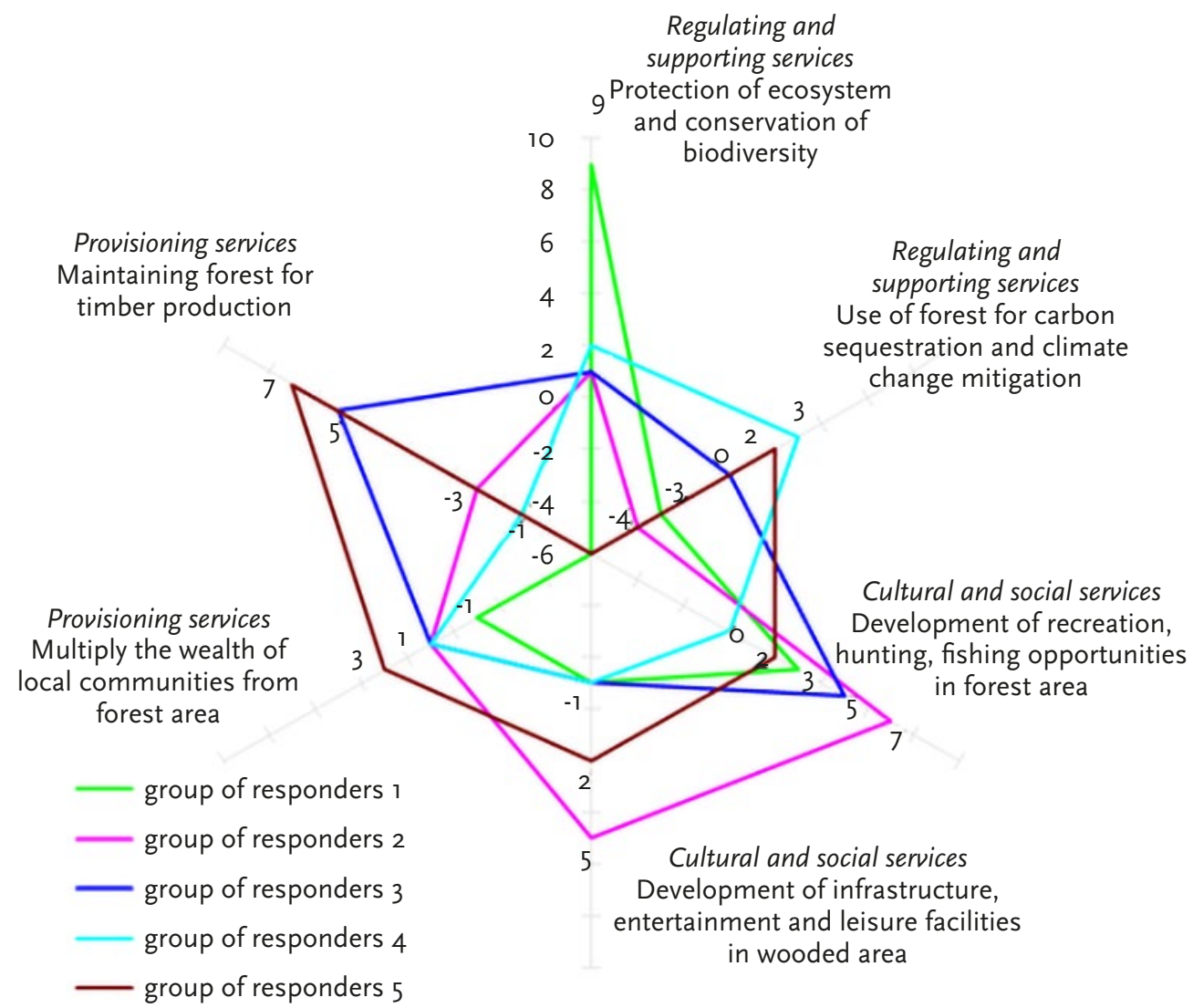

Figure 4. Heterogeneity of stakeholder preferences with regard to forest ecosystem services and the trade-offs, as identified by the $\mathrm{Q}$ analysis. Source: Nijnik et al. 2016

to become apparent and can be recognized. Peters et al. (20I5) documented that across five European countries (Finland, Germany, Norway, Slovenia and Spain) stakeholders perceive the synergies and trade-offs between ecosystem services provided by plantations in a surprisingly similar way: a strong synergy between production and employment but trade-offs with biodiversity conservation.

Attitudinal analysis conducted in the Netherlands, Poland, Romania, Sweden and Scotland (Nijnik et al. 20I0) showed that respondents from all these countries are well represented in the attitudinal group that strongly supports biodiversity conservation. This attitudinal group has a particularly strong representation in Poland, while in Scotland, the Netherlands and Sweden (in comparison with Poland and Romania) people seem to be more willing to balance the provision of multiple ecosystem services, and have more interest in production forestry. Differences in participants' preferences across countries could be explained by the diverse institutional environments, competences, capacities and capabilities, influencing stakeholder preoccupation with multiple opportunities, problems and consequences of forest resource use. Apparently, these attitudinal differences have deeper roots than certain visible aspects of human behaviour and are dependent upon the socio-economic, political and historical preconditions, cultural standards and ethical principles. Willingness to engage in tree planting is also influenced by culture and the legacy of the past (Nijnik and Mather 2008), by landholders' perceptions of its potential to provide a diversified income stream, and its impacts on flexibility of land management (Schirmer and Bull 20I4).

If forest plantations are established for business purposes, small-scale afforestation by local residents (when the profits are likely to remain in the communities) is less likely to cause conflict than the establishment of plantations by large-scale corporations 
(Schirmer and Bull 20I4). Small-scale plantations that have co-benefits for the environment tend to be perceived as the most desirable among landowners as well as among citizens, and in small-scale plantations the economic objective of wood production can also be met more sustainably, if forest-based activities and forest management are carefully designed. Forest plantations, however, might not be perceived as preferable by landholders, if their land is needed for more profitable uses, such as agriculture. Duesberg et al (2013) showed that this perception has influenced landowners in England, Spain, Finland, Scotland and Ireland.

\subsection{Institutional settings, social innovation and governance structures}

In Europe there is no common forest policy, and national forest laws and regulations are the major influence on the creation and management of forest plantations. However, European forestry is strongly influenced by international and the EU climate, energy and agricultural policies, and policy support is important for developing plantation forestry.

In the EU, the Common Agricultural Policy provides funds to member states for agriculture, including forestry. CAP funding supports the forestry sector through a wide range of measures: afforestation and woodland creation, new agroforestry systems and small-scale land care, prevention of damage, climate resilience and environmental value of ecosystem services, technologies and marketing of forest products, land management contracts for forest-environmental-climate services and biodiversity conservation. Experience shows that support of this type, whether national, EU or international, is critical in establishing and maintaining sustainable forestry and wood processing sectors (see section 2.4 on economic sustainability). In future these type of policies, and moving forward will also be important in achieving biodiversity, climate mitigation objectives and in developing the bioeconomy (section 4.3). Agroforestry $y^{5}$ and smaller scale woodland systems, as well as integrated crop-livestock-tree systems based on the development of mixed farming systems and agroforestry are currently of particular interest, since both have a strong potential to contribute to

5 See www.eurafagroforestry.eu/afinet meeting the UN Sustainable Development Goals, specifically concerning climate, rural development and bioeconomy considerations. This is likely to increase the use of this and other climate smart and resilient farming/plantation systems in Europe and bring them higher up the political agenda.

Various laws and regulations are designed to improve the sustainability of forest plantations, and they are encouraged by market incentives and various policy instruments. Specifically, forest certification as a governance mechanism has been introduced to realize social interest. Its realization is precariously dependent not only on information sharing about how certified forest products promote sustainability or fair trade, but also on the market returns on the investment in certification (Agrawal et al. 2018).

Overall, the existing and advancing institutional settings, and public and market-based governance arrangements are important for targeting sustainability in plantation forestry. However, they may overlook the realities and aspirations of forest-dependent communities (Agrawal et al. 20I8; Nijnik et al. 2019).

In this regard, social innovations ${ }^{6}$ associated with reconfiguring social practices based on existing perceptions of sustainable forest management primarily aim to secure continuance of local ways of life and an increase in human wellbeing. There are many triggers and enabling factors (power dynamics and values of participants) that precondition the success/failure of an outcome of a participatory process which lies at the core of social innovations. A participatory process may not be successful if there are insufficient capabilities or resources to facilitate the process, or no culture for participation.

Sustainability in forestry is perceived as a sense of unity and identity of forest-dependent peoples together with good social relationships within forest communities and towards other stakeholders (e.g. neighbouring communities, forest companies, authorities). Such relationships benefit from having local stewardship which respects people and nature. It is crucial therefore for the success of plantation forestry that it is taken forward together with the revitalization of forest-dependent communities. For this to happen forest management needs to be

6 For examples see the $\mathrm{H} 2020$ project SIMRA (Social Innovation in Marginalised Rural Areas), www.simra-h2020.eu 
considered as economically and socially beneficial for people, providing the basis for them to keep living in the locality and experiencing increases in their wellbeing. Social innovations around reconfiguring rules for the management of forests include collaborative management groups for planning logging, changing ownership, introducing innovative grassroots practices to monitor sustainability, and pilot projects (e.g. of agroforestry and mixed farming systems) to introduce new participatory practices in forest management.

\subsection{Key messages}

- Historical context, cultural settings, existing attitudes and perceptions about the social acceptability of plantations by landowners may be more important predictors for engagement of plantation creation and management than markets and prices.
- Acknowledging the multiplicity of relevant stakeholders, the heterogeneity of their perceptions and the role of social innovations is important for designing and implementing sustainable forest policy measures to govern the development of forest plantations.

- There is no "one-size-fits all solution" for plantation forestry across Europe's diverse geographi$\mathrm{cal}$ areas and different institutional and social settings, as there is a large diversity in the ways to manage and establish plantations to maximize socio-economic benefits. When pursuing plantation management, it is therefore important to consider case and context specificity and the diversity of options available. 


\section{Outlook for the future}

Forest products markets across the world are undergoing striking structural changes, with a major decline in demand for some established forest products, an economic downturn particularly in Western Europe, but with the simultaneous emergence of new markets and businesses (Hetemäki and Hurmekoski 20I6). The forest sector has a significant impact on the European economy and environment but there is not a clear understanding of how future socio-economic changes will affect plantation forestry in Europe and globally (Nepal et al. 20I9). The consumption and production of wood-based products is increasingly shifting from the formerly prominent regions of North America, Western Europe and Japan to the rapidly growing large economies of China, Brazil and India. This shift is expected to influence the outlook for forest plantations and for the global forest product markets (Nepal et al. 20I9). The ongoing development of the global bioeconomy may cause an increase in global roundwood demand in some regions, in others it does not necessarily entail a major change to the existing situation.

Despite the development of the bioeconomy and of new forest-based products and the increasing uptake of bioenergy, many traditional forest products, such as communication papers, are declining, which results in reduced demand for roundwood. It is also anticipated that in the circular bioeconomy many new products will be based on improving the performance of the entire value chain by using raw materials which are side-streams of current products (by-products or residues). These approaches may not cause increases in the demand for industrial roundwood in the same way that the increased use of conventional products can increase demand (Hetemäki and Hurmekoski 20I4 and 20I9).

Textiles, liquid biofuels, platform chemicals, plastics and packaging are new forest-based bioproducts which often substitute for fossil-based products, and that particularly have the potential to alleviate declining profits from communication paper (Hurmekoski et al. 20I8). Although many of the possible new products can utilize by-products from current wood processing chains, there could also be increases in primary wood use, mainly in the construction and textile markets (Hurmekoski et al. 20I8). Wood panels and engineered wood products, as well as packaging paper and paperboard have been growing strongly over the past decade. According to Hurmekoski et al. (2018), gaining $1-2 \%$ market share for these new wood-based products in total global markets would compensate for the losses from declining demand for communication paper. This would correspond to between a Io and $43 \%$ increase in revenues and an increase of between 2 and $21 \%$ in current industrial roundwood use in the USA, Canada, Sweden and Finland. However, these predictions are based on hypothetical assumptions and the market shares can be larger or smaller, while the turnover depends on unit prices of products and at which stage of the value chain the industry is assumed to operate.

Globally, fuel wood demand is decreasing, but in Europe it has been increasing due to bioenergy policies. Furthermore, several studies suggest that there is a large potential for additional and sustained harvesting of wood for bioenergy in Europe (Nabuurs et al. 2018). However, there are concerns over the sustainability of wood-based energy. O'Brien and Bringezu (20I7) present a scenario analysis which shows that if the EU meets around $40 \%$ of its renewable energy targets from roundwood, then wood consumption will overshoot EU reference values for sustainable supply capacities in 2030 . The reduction of fuel wood use by providing more efficient energy technologies, and using increasingly other sources of energy (solar, wind, etc.) could be a way to limit the demand for wood, especially outside Europe. Solberg et al. (2014) reviewed five recent studies of the effects of renewable energy sources and climate policies in Europe, confirming that the interactions are complex and concluding that continuing research on the outlook and impacts of biomass markets is essential to inform policy. The sectoral boundaries and actors included in forest-based value chains will be increasingly challenging to define. The established forest-based industries already provide a whole array of raw material and intermediate products (e.g. energy chips, sawnwood, pulp) to higher-value added end-product producers (Hurmekoski et al. 20I8). The foreseeable changes are producing a growing diversity and complexity in the forest sector and its value-chains, presenting what are likely to be ever greater economic and policymaking challenges in Europe and worldwide in the future. 
While at first sight it might be assumed that goals for climate mitigation and the development of the bioeconomy will increase future demand for roundwood, the above analysis indicates that future demand-supply interactions will be complex. Demand may not necessarily increase significantly in the EU. As discussed earlier in this report markets can react to increasing demand through prices, which in turn can dampen demand. In addition, very recently there has been pressure to increase forest sinks, which is sometimes thought to mean the limitation of harvesting, as well as increasing afforestation. To achieve balanced and sustainable production and consumption will require innovation across the value chain and in the development of business models - the new "equilibrium" described in chapter 2.

Forest-related responses to tackling climate change are now known to be a cost-effective option both globally (IPCC 20I9) and within Europe (Nabuurs et al. 20I8; Leskinen et al. 20I8). While carbon storage in the forest may be maximized in some undisturbed stands (Pihlainen et al. 20I4), taking the full carbon cycle and substitution effects into account produces higher climate benefits when stands are managed (Gustavsson et al. 20I7). Furthermore the climate benefits of forest management are optimized when wood is substituted for fossil-fuel intense materials and fossil fuels. This has recently been confirmed for European beech and Norway spruce in medium intensity managed stands in central Europe (Schulze et al. 20I9). Thus the case for combining plantation forestry with bioenergy and Carbon Capture and Storage (BECCS) as part of Europe's climate policies is becoming strong. The IPCC (20I9) recommends forest protection, sustainable forest management and forest restoration, but also recognizes the problem of policies and financial systems that do not take account of the full value of forests. To be cost-effective, forestry measures need to be specific to the local context and to ensure synergies with land restoration and food security. Forest plantations are important in landscape restoration and it has also been shown that the largest carbon sinks are created by the regrowth of young forests on non-forest areas or in deforested areas (Pugh et al. 2019).

Bastin et al. (2019) is the most recent of a number of studies that have looked at the land availability for woodland creation to meet future global demand across conventional, bioenergy and bioeconomy markets and for climate mitigation. They estimate the global technical potential to be as high as 900 million hectares which includes significant areas in Europe although, in practice, the area is likely to be smaller due to socio-economic and environmental considerations. Analysis of land availability in Europe has mostly considered the rising demand to meet bioenergy use from both annual crops and trees. Land availability varies with some areas having 0 to $6.5 \%$ "surplus" land available for biomass production and others with as much as 31\% (de Wit and Faaij 20I0). The cost of forestry also varies across Europe with some areas having both high land availability and low production costs. Where land use strategies are in place, afforestation tends to be targeted at marginal land (land with lower agricultural returns), abandoned land and derelict or contaminated land. Many of the modelling studies protect the land necessary for food production although in some land-use scenarios the intensification of agricultural production or dietary changes are also assumed. Overall land availability does not emerge as a major constraint and increasing the mobilization of forest products from existing forest lands through more intensive management would also help to meet future demand.

The Paris Agreement moved forward the way in which land use, land-use change and forestry (LULUCF) would be accounted for in the United Nations Framework Convention on Climate Change (FCCC). This is to be welcomed, not least because if forests are excluded from climate mitigation strategies, there would be no incentive for conservation of the current forest sink or bioeconomy, and no disincentive for deforestation and over-use of forest resources. Under the Paris Agreement countries pledge climate mitigation targets in their Nationally Determined Contributions (NDCs), and $25 \%$ of globally aggregated NDCs is expected to come from LULUCF measures - mainly the reduction in deforestation in Brazil's and Indonesia's NDCs.

The EU has adopted a legislative regulation to govern the incorporation of LULUCF measures into its 2030 Climate and Energy Framework. Under this regulation only that part of the forest management sink which exceeds a predefined forest reference level will count towards the target. This ensures that removal of carbon from the atmosphere will only be credited if it arises from additional actions. The EU legislation has capped the amount of 
possible credits from managed forest land (at 3.5\% of 1990 emissions) and also the maximum contribution allowable from LULUCF. However, forests can also contribute to mitigation indirectly especially through the utilization of wood as an energy and material source in place of fossil fuels and by using wood in place of high carbon cost materials such as steel and cement (product substitution - see Leskinen et al. 20I8).

On average across all NDCs submitted under the FCCC Paris Agreement, measures under LULUCF make up $24 \%$ of GHG reduction plans, while LULUCF measures are likely to make up only i\% of EU measures (Grassi et al. 2019). However, modelling work indicates that in Europe as a whole the potential contribution from forests is much higher (Nabuurs et al. 2018), and in some European countries (Spain, France, Italy, Germany and the UK) the potential contribution of afforestation and reforestation is also estimated to be high.

The case studies presented in this report give an indication of how the circumstances described above are impacting on forestry policy in European countries. In Ireland, afforestation is expected to be the largest contributor to the portion of the 202I to 2030 target which is allowable under LULUCF. Sweden adopted a climate act in 2017 which aims to achieve zero GHG emissions in 2045 and negative emissions thereafter. The importance of forestry in Sweden's GHG balance is clear when one considers that Sweden's total 20I6 GHG emissions were c. 9 million tons $\mathrm{CO}_{2}$ equ when LULUCF was included, but rise to about 52.9 million tons $\mathrm{CO}_{2}$ equ when LULUCF is excluded (National Forestry accounting plan for Sweden 20I9). Forestry measures are a significant part of Georgia's NDC7. In this, Georgia's government commits to establish sustainable forest management, to conduct afforestation/ reforestation and assist natural regeneration, and to expand the protected forest area. Further measures such as a commitment to afforestation/reforestation of up to 35000 hectares are conditional on external financial and technical support. In addition, Georgia is one of a number of countries that has made an ambitious commitment to reforestation under the Bonn Challenge.
The use of plantation forests as an integrated part of landscape restoration is also likely to increase in future. Attitudes towards restoration have undergone a paradigm shift over the past io years. The Bonn Challenge was launched in $201 \mathrm{II}$ to restore 150 million hectares, globally, by 2020 ; and in 20I4, the UN's New York Declaration increased the target to 350 million hectares by 2030. It is estimated that the initiative will generate US\$I70 billion/y in net benefits.

It is likely that the global demand for wood products will continue to be the main ecosystem service which allows forest enterprises to be profitable. This will produce pressure for the intensification of production which can threaten biodiversity (see section 4.I.). In general, European forestry seeks to provide a number of ecosystem services from the same forests - multifunctionality - although the scale at which diversity of ES provision is accommodated has become an issue. The challenges are to design and manage plantations in ways which can cope with climate change (this could become even more challenging with increased drought and a global warming above $2^{\circ} \mathrm{C}$ ), limit the threat from pests and pathogen (see chapter 3 ) and how to achieve a balance of ecosystem services at the landscape or ecosystem scale (see chapter 4). The area of plantation forestry is increasing in Europe and the proportion of roundwood and other services provided by plantation forests is increasing. Plantation forestry will become more important in meeting the future demand for wood, wood products and ecosystem services (see chapters 2, 4 and 5). Plantation forestry is also increasingly changing from large-scale investments in monocultures to small or medium-scale investments in which local households and communities are owners or co-owners as well as being employed in forestry and wood processing. In Europe plantation forestry already plays a significant role in meeting environmental, economic and climate needs, and given further investments and sustainable forest management, these can be enhanced in the future. 


\section{Policy implications and recommendations}

Plantation forests are important resources which can contribute to a number of high priority policy objectives, such as the Paris Agreement and SDGs.

- In Europe plantation forestry already plays a significant role in meeting environmental, economic and climate needs and further investments could enhance these contributions. Both research and policy measures are needed to support the establishment, ongoing sustainable management (SFM) and utilization of plantation forests.

- Research, guidance and regulation will continue to be required on the identification and production of forest reproductive materials for plantations. Species and the forest reproductive material itself should be selected not only for their production ability, but also for their ability to maintain or enhance the capacity of the forest to adapt to climate change.

- Owners and managers need to be aware that the risks related to plantation forests are currently increasing, due to growing abiotic, biotic and financial hazards. To mitigate risk, adaptation of forest management is necessary. The first option is to improve resistance by increasing plantation diversity. This could be done by combining complementary tree species within stands and using mosaics of different forest types at the landscape level. The second option is to reduce the exposed standing volume by shortening thinning and harvesting regimes (e.g. by shortening rotation length).

- Sustained yield under climate change conditions requires resilient plantations and will become very difficult if average warming exceeds $2^{\circ} \mathrm{C}$. Resilience and sustainability can be achieved if regulations, incentives and practice guides specify science-based approaches to control standing stock and age class distribution in plantation forests with the use of species mixtures and other elements of risk management.

- To develop new sustainable and multifunctional plantation forests, economic policy measures focused on increasing the efficiency of timber supply should be complemented with well-targeted measures to preserve forests and conserve their biodiversity and landscape values.
- Large forest plantation schemes need to go hand in hand with a genetic conservation plan, addressing both tree genetic resources and fauna and flora in general. Land sharing and land sparing are equally valid conservation options that need consideration in a sustainable primary production landscape.

- Even intensively managed plantation forests have lower land use impact than agricultural systems. To some extent their intensification increases land use efficiency, but there is an optimum beyond which further intensification does not contribute much to increase productivity, while strongly harming the environment, including adjacent or downstream ecosystems.

- Even when focused on wood provision, plantations can also contribute strongly to regulatory and social ecosystem services, especially carbon sequestration and recreation. Forest plantations, and where suitable, agroforestry need to be integrated components of landscape scale restoration and management.

- Acknowledging the multiplicity of relevant stakeholders, the heterogeneity of their perceptions and the role of social innovations is important for designing and implementing sustainable forest policy measures.

- The methodologies for establishing and managing plantation forests are diverse and vary regionally across Europe. Thus there is no "one-size-fits all solution" to maximize socio-economic benefits and ongoing research support is required.

- For European forests to supply the circular biobased economy, research, policies and strategies need to be coordinated across the entire value chain from plantation establishment and management through to delivery of products and services. 


\section{References}

Agrawal A., Hajjar R., Liao C., Rasmussen L. V. and Watkins C. 20I8. Editorial overview: Forest governance interventions for sustainability through information, incentives, and institutions. Current Opinion in Environmental Sustainability, 32, AI-A7. https://doi.org/ıo.1016/j.cosust.2018.08.002

Baeten L., Bruelheide H., van der Plas F., Kambach S., Ratcliffe S., Jucker T., Allan E., Ampoorter E., Barbaro L., Bastias C.C., Bauhus J., Benavides R., Bonal D., Bouriaud O., Bussotti F., Carnol M., Castagneyrol B., Charbonnier Y., Chećko E., Coomes D.A., Dahlgren J., Dawud S.M., De Wandeler H., Domisch T., Finér L., Fischer M., Fotelli M., Gessler A., Grossiord C., Guyot V., Hättenschwiler S., Jactel H., Jaroszewicz B., Joly F-X., Koricheva J., Lehtonen A., Müller S., Muys B., Nguyen D., Pollastrini M., Radoglou K., Raulund-Rasmussen K., Ruiz-Benito P., Selvi F., Stenlid J., Valladares F., Vesterdal L., Verheyen K., Wirth C., Zavala M.A. and Scherer-Lorenzen M. 20I9. Identifying the tree species compositions that maximize ecosystem functioning in European forests. Journal of Applied Ecology, 56(3), 733-744. https://doi.org/I0.IIII/1365-2664.I3308

Bastin, J-F., Finegold Y., Garcia C., Mollicone D., Rezende M., Routh D., Zohner C.M. and Crowther T.W. 2019. The global tree restoration potential. Science 365(6448), 76-79. https://doi.org/I0.II26/science.aaxo848

Boyd I.L., Freer-Smith P.H., Godfray H.C.J. and Gilligan C.A. 20I3. The global importance of tree pests and diseases. Science 342. https://doi.org/IO.II26/science.I235773

Branco M., Brockerhoff E. G., Castagneyrol B., Orazio, C. and Jactel, H. 2015. Host range expansion of native insects to exotic trees increases with area of introduction and the presence of congeneric native trees. Journal of Applied Ecology, 52(I), 69-77. https://doi.org/ıo.IIII/1365-2664.12362

Branco M., Battisti A. and Mendel Z. 20I6. Foliage feeding invasive insects: defoliators and gall makers. In: Paine T., Lieutier F. (eds) Insects and Diseases of Mediterranean Forest Systems. Springer, Cham. https:// doi.org/I0.1007/978-3-3I9-24744-I_8

Brockerhoff E.G. and Liebhold A.M. 20I7. Ecology of forest insect invasions. Biological Invasions, I9(II), 3I4I3159. https://doi.org/I0.I007/SI0530-0I7-I5I4-I

Cincotta C.L., Adams J.M. and Holzapfel C. 2009. Testing the enemy release hypothesis: a comparison of foliar insect herbivory of the exotic Norway maple (Acer platanoides L.) and the native sugar maple (A. saccharum L.). Biolol Invasions, II(2), 379-388. https://doi.org/I0.I007/sio530-008-9255-9

Cristan R., Aust W.M., Bolding M.C., Barrett S.M., Munsell J.F. and Schilling E. 20I6. Effectiveness of forestry best management practices in the United States: Literature review. Forest Ecology and Management, 360, I33-I5I. https://doi.org/10.I0I6/j.foreco.2015.10.025

Cucchi V. and Bert D. 2003. Wind-firmness in Pinus pinaster Ait. stands in Southwest France: influence of stand density, fertilisation and breeding in two experimental stands damaged during the I999 storm. Annals of Forest Science, 60(3), 209-226. https://doi.org/10.1051/forest:2003013

De Wit M. and Faaij A. 20I0. European biomass resource potential and costs. Biomass and Bioenergy 34 (2) I88-202 https://doi.org/10.I0I6/j.biombioe.2009.07.0II

Duesberg S., O’Connor D. and Dhubháin Á.N. 2013. To plant or not to plant-Irish farmers' goals and values with regard to afforestation. Land use policy 32: I55-I64. https://doi.org/IO.IOI6/j.landusepol.20I2.IO.O2I

Dulaurent A.M., Porté A.J., van Halder I., Vetillard F., Menassieu P. and Jactel H. 20I2. Hide and seek in forests: colonization by the pine processionary moth is impeded by the presence of nonhost trees. Agricultural and Forest Entomology, I4(I), I9-27. https://doi.org/I0.IIII/j.I46I-9563.20II.00549.x

Duncker P.S, Barreiro S.M, Hengeveld G.M, Lind T., Mason W.L., Ambrozy S. and Spiecker H. 2012. Classification of Forest Management Approaches: A New Conceptual Framework and Its Applicability to European Forestry. Ecology and Society I7(4): 51. https://doi.org/I0.575I/es-05262-I7045I

EEA 2006. How much bioenergy can Europe produce without harming the environment? European Environment Agency Report No 7.

European Commission. 2013. A new EU Forest Strategy: for forests and the forest-based sector. Brussels, 20.9.2013 $\operatorname{COM}(2013) 659$ final.

FAO 2018 Global Forest resources Assessment 2020 Terms and Definitions. FAO Forest Resources Assessment working paper 188 . 
FAO, IUFRO et al. 20I8. Planted forests: a solution for green development. Summary report of the fourth international congress on planted forests, Beijing, China, October 2018. I6 p.

Faustman M. I849. Berechnung des Werthes, welchen Waldboden, sowie noch nicht haubare Holzbestände für die Waldwirthschaft besitzen. Allgemeine Forst- und Jagdzeitung, Dezember, pp 44I-45I.

Grassi G., Cescatti A., Matthews R., Duveiller G., Camia A., Federici S., House J., Noblet-Ducoudre N., Pilli R. and Vizzarri, M. 20I9. On the realistic contribution of European forests to reach climate objectives. Carbon balance and Management I4(8), I-5. https://doi.org/IO.II86/si302I-0I9-0I23-y

Gustavsson L., Haus S., Lundblad M., Launndstrom A., Oritiz C.A., Sathre R., Le Truong N. and Wikberg P-E. 20I7. Climate change effects of forestry and substitution of carbon-intensive materials and fossil fuels. Renewable and Sustainable Energy Reviews 67, 612-624 https://doi.org/ı0.Ioı6/j.rser.2016.09.056

Hartman R. I976. The harvesting decision when a standing forest has value. Economic Inquiry I6, 5-I2.

Hartmann H., Moura C.F., Anderegg W.R., Ruehr N.K., Salmon Y., Allen C.D., Arndt S.K., Breshears D.D., Davi H., Galbraith D., Ruthrof K.X., Wunder J., Adams H.D., Bloemen J., Cailleret M., Cobb R., Gessler A., Grams T.E.E., Jansen S., Kautz M., Lloret F. and O’Brien M. 2018. Research frontiers for improving our understanding of drought-induced tree and forest mortality. New Phytologist, 2I8(I), I5-28. https://doi. org/ıO.IIII/nph.I5048

Hemström K., Mahapatra K. and Gustavsson L. 20I4. Public perceptions and acceptance of intensive forestry in Sweden. Ambio 43(2): I96-206. https://doi.org/10.1007/si3280-013-04II-9

Hetemäki L., Hanewinkel M., Muys B., Ollikainen M., Palahí M. and Trasobares A. 20I7. Leading the way to a European circular bioeconomy strategy. From Science to Policy 5. European Forest Institute. https://doi. org/10.36333/fso5

Hetemäki L. and Hurmekoski E. 20I4. Forest products market outlook. In: Hetemäki L. (ed). 20I4. Future of the European forest-based sector: Structural changes towards bioeconomy. What Science Can Tell Us 6. European Forest Institute.

Hetemäki L. and Hurmekoski E. 20I6. Forest Products Markets under Change: Review and Research Implications. Curr Forestry Rep, 2, I77-188. https://doi.org/I0.1007/s40725-016-0042-Z

Hetemäki L. and Hurmekoski E. 20I9. Forest bioeconomy development: markets and industry structures. In Nikolakis W. and Innes J. (eds). The Wicked Problem of Forest Policy. Cambridge University Press (forthcoming).

Hurmekoski E., Jonsson R., Korhonen J, Janis J., Mäkinen M., Leskinen P. and Hetemäki L. 20ı8. Diversification of the forest industries: Role of new wood-based products. Canadian Journal of Forest Research 48(I2), I4I7-I432. https://doi.org/ıo.I139/cjfr-2018-oII6

IPCC 2019. Climate Change and Land, an IPCC special report on climate change, desertification, land degradation, sustainable land management, food security, and greenhouse gas fluxes in terrestrial ecosystems (SRCCL). Intergovernmental Panel on Climate Change, Geneva, Switzerland.

Jactel H., Branco M., Duncker P., Gardiner B., Grodzki W., Langstrom B., Moreira F., Netherer S., Nicoll B., Orazio C., Piou D., Schelhaas M.J. and Tojic K. 20I2. A multicriteria risk analysis to evaluate impacts of forest management alternatives on forest health in Europe. Ecology and Society, I7(4). https://doi.org/IO.575I/ es-04897-I70452

Jactel H., Bauhus J., Boberg J., Bonal D., Castagneyrol B., Gardiner B., Gonzalez-Olabarria J.R., Koricheva J., Meurisse N. and Brockerhof, E.G. 20I7. Tree diversity drives forest stand resistance to natural disturbances. Current Forestry Reports, 3(3), 223-243. https://doi.org/I0.I007/s40725-0I7-0064-I

Jactel H., Koricheva J. and Castagneyrol B. 20I9. Responses of forest insect pests to climate change: not so simple. Current Opinion in Insect Science, 35: 103-I08. https://doi.org/I0.10I6/j.cois.2019.07.010

Jurgensen C., Kollert W. and Lebedys A. 20I4. Assessment of industrial roundwood production from planted forests (No. 48), Working paper series. FAO, Rome.

Kelly R., Chipman M.L., Higuera P.E., Stefanova I. and Brubaker L.B., Hu F.S. 20I3. Recent burning of boreal forests exceeds fire regime limits of the past I०,০০০ years. Proceedings of the National Academy of Sciences, IIo(32), I3055-I3060. https://doi.org/10.1073/pnas.I305069IIo 
Konnert M., Fady B., Gömöry D., A’Hara S., Wolter F., Ducci F., Koskela J., Bozzano M., Maaten T. and Kowalczyk J. 20I5. Use and transfer of forest reproductive material in Europe in the context of climate change. European Forest Genetic Resources Programme (EUFORGEN), Bioversity International, Rome, Italy. xvi and 75 p.

Kwon T.S., Shin J.H., Lim J.H., Kim Y.K. and Lee E.J. 20II. Management of pine wilt disease in Korea through preventative silvicultural control. Forest ecology and management, 26I(3), 562-569. https://doi.org/I0.IOI6/j. foreco.2010.II.008

Lawrence A., Spinelli R., Toppinen A. and Salo E. 20I7. What are the implications of the bioeconomy for forest-related jobs? In: Winkel, G. (ed.) Towards a sustainable bioeconomy - assessment and the way forward. What Science Can Tell Us 8, European Forest Institute.

Le Tacon F., Bonneau M., Gelpe J., Boisseau T. and Baradat P.H. I994. Le dépérissement du pin maritime dans les Landes de Gascogne à la suite des introductions de graines d'origine ibérique et des grands froids des années I962-I963 et I985. Revue forestière française 5, 474-484. https://doi.org/I0.4267/2042/26575

Leskinen P., Cardellini G., González-García S., Hurmekoski E., Sathre R., Seppälä J., Smyth C., Stern T. and Verkerk P.J. 20I8. Substitution effects of wood-based products in climate change mitigation. From Science to Policy 7. European Forest Institute. https://doi.org/I0.36333/fso7

Lindenmayer D.B., Franklin J.F; Löhmus A., Baker S.C., Bauhus J., Beese W., Brodie A., Kiehl B., Kouki J., Martínez Pastur G., Messier C., Neyland M., Palik B., Sverdrup-Thygeson A., Volney J., Wayne A. and Gustafsson L. 20I2. A major shift to the retention approach for forestry can help resolve some global forest sustainability issues. Conservation Letters, 5(6), 42I-43I. https://doi.org/IO.IIII/j.I755-263X.20I2.00257.x

Maes W.H., Heuvelmans G. and Muys B. 2009. Assessment of land use impact on water-related ecosystem services capturing the integrated terrestrial-aquatic system. Environmental Science \& Technology 43: 73247330. https://doi.org/10.I02I/es9006r3w

Martínez-Alvarado O., Gray S.L., Hart N.C., Clark P.A., Hodges K. and Roberts M.J. 2018. Increased wind risk from sting-jet windstorms with climate change. Environmental Research Letters, I3(4), 044002. https:// doi.org/ı0.1088/1748-9326/аaаeza

Nabuurs, G-J., Verkerk P.J., Schelhaas M-J., Olabarria J.R.G., Trasobares A. and Cienciala E. 2018. Climate-Smart Forestry: mitigation impacts in three European regions. From Science to Policy 6. European Forest Institute. https://doi.org/10.36333/fso6

Nepal P., Korhonen J., Prestemon J.P. and Cubbage F.W. 20I9. Projecting global planted forest area developments and the associated impacts on global forest product markets. Journal of Environmental Management. https://doi.org/Io.IoI6/j.jenvman.2019.03.126

Nijnik M, 2004. To an economist's perception on sustainability in forestry-in-transition. Forest Policy and Economics 6: 403-4I3. https://doi.org/10.1016/j.forpol.2004.03.014

Nijnik M. and Mather A. 2008. Analyzing public preferences concerning woodland development in rural landscapes in Scotland. Landsc. Urban Plan. 86 (3-4): 267-275. https://doi.org/1o.ioi6/j.landurbplan.2008.03.007

Nijnik M. and Miller D. 20I4. Targeting sustainable provision of forest ecosystem services with special focus on carbon sequestration. In: Matyssek R., Clarke N., Cudlin P., Mikkelsen T., Tuovinen J-P., Wiesser G. and Paoletti E. (eds.). Climate Change, Air Pollution and Global Challenges: Understanding and Perspectives from Forest Research, Elsevier, Amsterdam, 547-565.

Nijnik M. and Miller D. 20I7. Valuation of ecosystem services: paradox or Pandora's box for decision-makers? One Ecosystem 2: (og Oct). https://doi.org/10.3897/oneeco.2.eI4808

Nijnik M., Nijnik A. and Brown I. 20I6. Exploring the linkages between multi-functional forestry goals and the legacy of spruce plantations in Scotland. Canadian Journal of Forest Research 46: 1247-1254. https:// doi.org/IO.II39/cjfr-2015-0399

Nijnik M., Nijnik A., Lundin L., Staszewski T. and Postolache C. 20Io. Stakeholder attitudes to multi-functional forests in Europe. Forests, Trees and Livelihoods I9 (4): 34I-358. https://doi.org/I0.I080/I472802 8.2010 .9752677

Nijnik M. and Pajot G. 20I4. Accounting for uncertainties and time preference in economic analysis of tackling climate change through forestry and selected policy implications for Scotland and Ukraine. Climatic Change I24 (3): 677-690. https://doi.org/I0.1007/sio584-0I4-1076-5 
Nijnik M., Secco L., Miller D. and Melnykovych M. 20I9. Can social innovation make a difference to forest-dependent communities? Forest Policy and Economics. Io०, 207-213. https://doi.org/ıo.Ioı6/j.forpol.2019.0I.00I

Nijnik M., Slee B. and Nijnik A. 20I4. Biomass production: impacts on other ecosystem services. In: Pelkonen P., Mustonen M., Asikainen A., Egnell G., Kant P., Leduc S. and Pettenella D. (eds). Forest Bioenergy for Europe. What Science Can Tell Us 4. European Forest Institute.

O’Brien M. and Bringezu S. 20I7. Assessing the Sustainability of EU Timber Consumption Trends: Comparing Consumption Scenarios with a Safe Operating Space Scenario for Global and EU Timber Supply. Land 6, 84; https://doi.org/10.3390/land6040084

Payn T., Carnus J.-M., Freer-Smith P., Kimberley M., Kollert W., Liu S., Orazio C., Rodriguez L., Silva L.N. and Wingfield M.J. 20I5. Changes in planted forests and future global implications. Forest Ecology and Management 352, 57-67. https://doi.org/10.1016/j.foreco.2015.06.02I

Peters D.M., Wirth K., Böhr B., Ferranti F., Górriz-Mifsud E., Kärkkäinen L., Krč J., Kurttila M., Leban V., Lindstad B.H., Pezdevšek Malovrh Š., Pistorius T., Rhodius R., Solberg B. and Zadnik Stirn, L. 20I5. Energy wood from forests-stakeholder perceptions in five European countries. Energy. Sustain. Soc. 5(I7). https://doi. org/ıo.II86/si3705-0I5-0045-9

Peters J., Garcia Quijano J., Content T., Van Wyk G., Holden N.M., Ward S.M. and Muys B. 2003. A new land use impact assessment method for LCA: theoretical fundaments and field validation. In: N. Halberg and B. Weidema. 4th International Conference on Life Cycle Assessment in the Agri-food sector: Linking environmentally friendly production and sustainable consumption. Bygholm Park Hotel, Denmark, 6-8 Oct 2003. Working papers, I54-I70.

Pihlainen S., Tahvonen O. and Niinimäki S. 20I4. The economics of timber and bioenergy production and carbon storage in Scots pine stands. Canadian Journal of Forest Research, 44(9): IO9I-IIO2, https://doi. org/ı.II39/cjfr-2013-0475

Pugh T.A.M., Lindeskog M., Smith B., Poulter B., Arneth A., Haverd V. and Calle L. 20I9. Role of forest regrowth in global carbon sink dynamics. PNAS II6 (го) 4382-4387. https://doi.org/10.1073/pnas.I8I05I2II6

Ribe R.G., Ford R.M. and Williams K.J.H. 2013. Clearfell controversies and alternative timber harvest designs: How acceptability perceptions vary between Tasmania and the U.S. Pacific Northwest. J. Environ. Manage. II4C: 46-62. https://doi.org/10.1016/j.jenvman.2012.09.029

Schelhaas M. J., Nabuurs G-J. and Schuck A. 2003. Natural disturbances in the European forests in the I9th and 2oth centuries. Global Change Biology, 9(II), I620-I633. https://doi.org/I0.I046/j.I365-2486.2003.00684.X

Schelhaas M.J., Hengeveld G., Moriondo M., Reinds G. J., Kundzewicz Z.W., Ter Maat H. and Bindi, M. 2010. Assessing risk and adaptation options to fires and windstorms in European forestry. Mitigation and Adaptation Strategies for Global Change, I5(7), 68I-70I. https://doi.org/10.1007/si1027-0I0-9243-0

Schirmer J. and Bull L. 20I4. Assessing the likelihood of widespread landholder adoption of afforestation and reforestation projects. Glob. Environ. Chang. 24:306-320. https://doi.org/10.10I6/j.gloenvcha.2013.II.009

Schulze E-D., Stupak I. and Hessenmoller D. 20I9. The climate mitigation potential of managed versus unmanaged spruce and beech forests in Central Europe. Chapter 7 in Bioenergy with Carbon Capture and Storage. Academic Press. https://doi.org/10.10I6/b978-0-12-816229-3.00007-7

Seidl R. and Rammer W. 20I7. Climate change amplifies the interactions between wind and bark beetle disturbances in forest landscapes. Landscape ecology, 32 (7), I485-I498. https://doi.org/Io.I007/sio980-oI6$0396-4$

Silva L.N., Freer-Smith P.H. and Madsen P. 20I8. Production, Restoration, Mitigation: a new generation of plantations. New Forests. https://doi.org/10.1007/siro56-018-9644-6

Sniezko R.A. and Koch J. 20I7. Breeding trees resistant to insects and diseases: putting theory into application. Biological invasions, I9(II), 3377-3400. https://doi.org/I0.I007/si0530-0I7-I482-5

Solberg B., Hetemäki L., Maarit A., Kallio I., Moiseyev A. and Sjølie H.K. 20I4. Impacts of forest bioenergy and policies on the forest sector markets in Europe - what do we know? EFI Technical Report 89. European Forest Institute. 
Van der Ven H. and Cashore, B. 20I8. Forest certification: the challenge of measuring impacts. Current Opinion in Environmental Sustainability, 32, I04-III. https://doi.org/10.I016/j.cosust.2018.06.00I

Wolfslehner B., Prokofieva I. and Mavsar R. (eds). 20I9. Non-wood forest products in Europe: Seeing the forest around the trees. What Science Can Tell Us io. European Forest Institute. 


\section{Country case studies}

\section{Republic of Ireland}

(see also Sitka spruce study in Figure I and Table I)

Due to centuries of exploitation and deforestation, forest cover was virtually depleted in Ireland by the turn of the $20^{\text {th }}$ century, occupying just I\% of the land area. Subsequent forest policy focused on afforestation, primarily on soils marginal to economic agriculture where species choice was limited to a narrow range of conifers suited to Atlantic forestry. From the mid-I980s onwards, afforestation efforts have been assisted by farmers who have planted forests aided by state grants and annual premium payments. Forest cover now occupies 770,000 ha (II\% of the land area); the area of planted forests is 666,000 ha with plantations actively managed for wood supply occupying 598,000 ha. Forest ownership is $50.8 \%$ public and $49.2 \%$ private.

Sitka spruce is the predominant species used in plantations (306,000 ha). The species produces excellent timber yields (average Mean Annual Increment - MAI I6-22 $\mathrm{m}^{3} \mathrm{ha}^{-\mathrm{I}}$ ), the timber has good strength to weight properties and produces excellent crops on marginal agricultural soils. For afforestation, the species is established at 2,500 stems ha ${ }^{-1}$ mixed with Io to $15 \%$ diverse broadleaves (birch or alder). Plantations typically have open space to cater for biodiversity and environmental objectives, there are usually trade-offs between production/ carbon sequestration and biodiversity objectives (see Figure 3, section 4.3).

First thinning commences at I 5 to 20 years where one third of the volume is removed by harvesting machine following line removal and selective thinning between lines. The majority of harvest in first thinning is pulpwood with a smaller proportion of roundwood used for the timber pallet industry and for the production of fencing stakes. Two further thinnings removing approximately $50 \mathrm{~m}^{3} \mathrm{ha}^{-1}$ on 4-year cycles occur before clear-cut takes place at 35 years. The aim is to produce structural timber (according to the EN I408I to Ci6 strength class).

Other species include lodgepole pine (Pinus contorta) (II\%), Norway spruce, (5\%) larch (4\%), birch $(4 \%)$ and ash (3\%) (Table 2). However recent outbreaks of Phytopthora ramorum in larch and Hymenoscyphus fraxineus in ash have presented challenges to species diversification as these are no longer used for plantation establishment.

Roundwood harvest in 2017 was 3.5 million $\mathrm{m}^{3}$, with the majority of the harvest sawn softwood and round stakes. The production of wood-based panels was $836,000 \mathrm{~m}^{3}$ in 2017 and the timber export market was valued at 423 million euros. Roundwood supply is forecasted to increase from 4.0 million $\mathrm{m}^{3}$ in 2016 to almost 8 million $\mathrm{m}^{3}$ by 2035 (Phillips et al. 20I6). However even with this increase, shortfalls of 3.0 to 4.7 million $\mathrm{m}^{3}$ per annum are predicted in certain sectors (i.e. energy markets) by 2025 (COFORD 20I8).

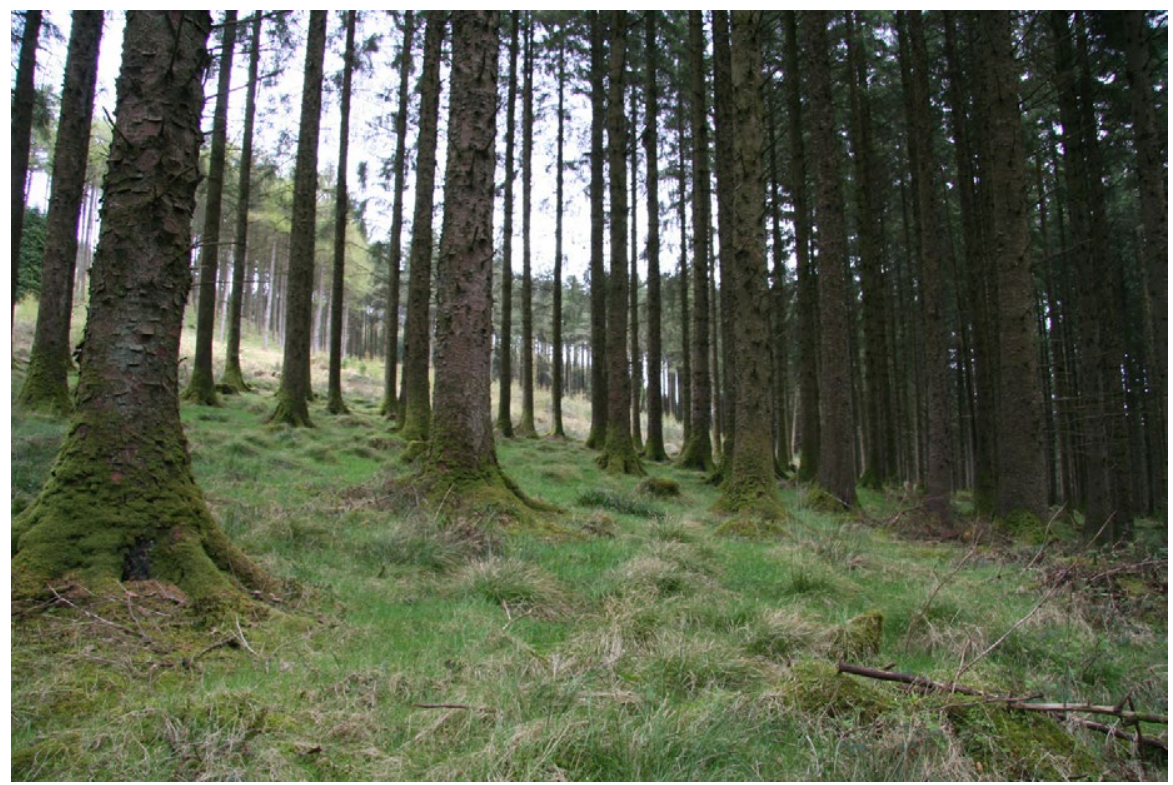

Figure 5. Mature Sitka spruce plantation used predominantly for the provision of construction grade timber. Photo by Niall Farrelly. 
Plantation forests play a key role in climate change mitigation in Ireland through a combination of $\mathrm{CO}_{2}$ sequestration, long term storage of carbon in harvested wood products and energy substitution (Forestry Act 20I7). The Paris Agreement allows for the use of $\mathrm{CO}_{2}$ eq. removals from land use, landuse change and forestry (LULUCF) for compliance with greenhouse gas reductions. Of the 26.8 million tons $\mathrm{CO}_{2}$ eq. removals allowable for Ireland's compliance with its 202I-2030 emission reduction target, afforestation will be by far the largest contributor representing 20 million tons $\mathrm{CO}_{2}$ eq.

Considerable challenges exist to the continued expansion of forest cover to I $8 \%$, as evidenced by the recent decline in planting levels $(<6,000$ ha per annum since 20I0). These serve to highlight the difficulty of promoting permanent land use change to forestry (COFORD 20I6). Further opportunities may exist to plant a considerable portion of land (circa I.3 million ha) marginal to economic agriculture (Farrelly and Gallagher 20I5), or for the incorporation of wood lots to provide biodiversity, climate and environmental objectives under future CAP Strategic Plans.

Due to the suitability of a range of productive coniferous species from the pacific north-west of America, the forest sector is now a significant land use in Ireland worth 2.3 billion euros per annum. The sector (growing forests, harvesting and wood processing activities) contributes about $\mathrm{I} \%$ to Ireland's national
GDP, giving rise to direct and indirect employment of about 12,000 people in downstream goods and services. Recent disease outbreaks highlight the need for increased vigilance so that the health and productivity of the resource is maintained and the maximum benefits of forests are realized.

\section{References}

COFORD Land Availability Working Group. 2016. Land availability for afforestation - Exploring opportunities for expanding Ireland's forest resource. COFORD, Dublin.

COFORD Wood Mobilisation and Production Forecasting Group. 20I8. Wood Supply and Demand on the Island of Ireland to 2025. Department of Agriculture, Food and the Marine, Dublin.

DAFM 20I7. Ireland's National Forest Inventory 20I7. Results. Government publications, 52 St. Stephens Green, Dublin 2, Ireland.

Farrelly, N. and Gallagher, G. 20I5. The potential availability of land for afforestation in the Republic of Ireland. Irish Forestry 72 (I\&2). I2O-I38.

Phillips, H., Corrigan, E., McDonagh, M., Fairgrieve, M., Farrelly, N., Redmond, J., Barrett, F. and Twomey, M. 20I6. All Ireland Roundwood Production Forecast 20I6-2035. COFORD, Department of Agriculture, Food and the Marine, Dublin.

Table 2. The net species area occurring in plantation forests in Ireland (source: DAFM 2017).

\begin{tabular}{|l|r|r|r|}
\hline & Afforestation & Reforestation & Total \\
\hline Sitka spruce (Picea sitchensis) & \multicolumn{2}{|c|}{ thousands ha } \\
\hline Norway spruce (Picea abies) & 203.08 & 103.39 & 306.47 \\
\hline Scots pine (Pinus splvestris) & 18.27 & 5.97 & 24.24 \\
\hline Other pines & 4.72 & 1.03 & 5.75 \\
\hline Douglas fir (Pseudotsuga menziesii) & 42.62 & 12.85 & 55.47 \\
\hline Larch spp. (Larix spp.) & 5.83 & 3.35 & 9.18 \\
\hline Other conifers & 14.92 & 8.03 & 22.95 \\
\hline Oak (Quercus spp.) & 1.52 & 0.82 & 2.34 \\
\hline Beech (Fagus spp.) & 9.50 & 1.88 & 11.38 \\
\hline Ash (Franixus excelsior) & 3.69 & 2.41 & 6.1 \\
\hline Sycamore (Acer pseudoplatanus) & 10.24 & 3.39 & 13.63 \\
\hline Birch spp. (Betula spp.) & 5.32 & 1.07 & 6.39 \\
\hline Alder (Alnus spp.) & 6.47 & 11.88 & 18.35 \\
\hline Long lived broadleaves & 8.12 & 2.49 & 10.61 \\
\hline Short lived broadleaves & 1.32 & 2.82 & 4.14 \\
\hline Total & 7.46 & 9.58 & 17.04 \\
\hline & 343.07 & 170.97 & 514.04 \\
\hline
\end{tabular}




\section{Sweden}

(see also Norway spruce study in Figure I and Table I)

Sweden has 28 million ha of forest and 20 inhabitants per square kilometre. Before the $20^{\text {th }}$ century, forests had been exploited for industrial purposes (e.g. mining in Central Sweden), transformed to agricultural land or degraded (southern Sweden). Large-scale afforestation started when a forestry act was adopted in 1903 with the aim of ensuring the continuous regeneration of wood material.

Currently, more than 150,000 ha of forest land are replanted yearly (YF 20I4). While spruce is most productive in southern Sweden (Mean Annual Increment MAI of $4^{-\mathrm{I} 4} \mathrm{~m}^{3} \mathrm{ha}^{-\mathrm{I}}$ ) and can yield Io $\mathrm{m}^{3} \mathrm{ha}^{-1}$ of stem wood on a typical site, Scots pine is more productive than Norway spruce on most sites in north Sweden (MAI 2-7 $\mathrm{m}^{3}$ ha $^{-1}$, SKS I984). Norway spruce also suffers less than Scots pine from browsing by moose (Alces alces). The non-native, fast-growing lodgepole pine (Pinus contorta) was introduced in the I980s in northern and central Sweden to achieve a more steady annual wood supply. Plantations of other tree species are less common (Table 3). By law, broadleaf stands of oak, beech and noble broadleaves cannot be transformed to conifer forest and the planting of these species is subsidized. However, planting Sitka spruce, larch and poplar species including hybrids has a higher potential to diversify future wood supply. These species cover approx. 30,000 ha today (Drössler 20I0). Also, birch occurs naturally in young conifer plantations and provides opportunities for the forest sector.

Recreational values are important in densely populated areas, and biodiversity conservation is achieved using set-aside areas, mostly. Providing the bulk of construction timber exported to many countries, Norway spruce is the most common forest type in the country and dominates the forest landscape in southern Sweden where broadleaf forest was once more abundant (Lindblad and Foster 20IO).

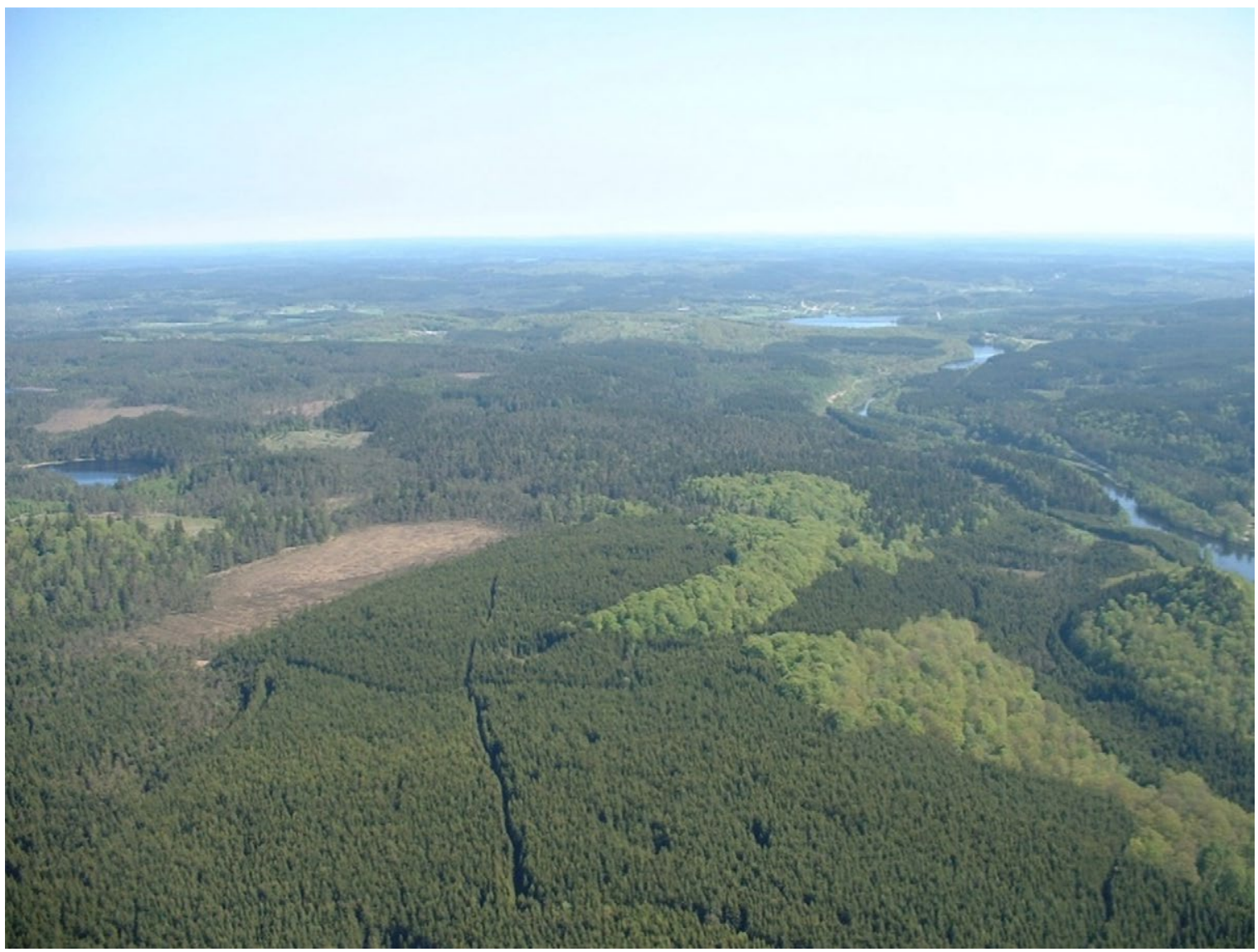

Figure 6. Southern Swedish forest landscape dominated by planted Norway spruce (Halland, photo by Örjan Fritz). 
Table 3. Proportion of planted seedlings (\%) per tree species on the forest area replanted in year 2013 (source: YF 2014).

\begin{tabular}{|l|l|l|l|l|l|l|l|}
\hline $\begin{array}{l}\text { Scots } \\
\text { pine }\end{array}$ & $\begin{array}{l}\text { Lodge- } \\
\text { pole pine }\end{array}$ & $\begin{array}{l}\text { Norway } \\
\text { spruce }\end{array}$ & $\begin{array}{l}\text { Other } \\
\text { conifers }\end{array}$ & Birch & $\begin{array}{l}\text { Other } \\
\text { broad- } \\
\text { leaves }\end{array}$ & $\begin{array}{l}\text { Total number of } \\
\text { planted seedlings }\end{array}$ & $\begin{array}{l}\text { Forest area re- } \\
\text { planted after final } \\
\text { harvest }\end{array}$ \\
\hline 36.2 & 4.2 & 56.7 & 1.8 & 0.4 & 0.7 & 381 million & 176,000 ha \\
\hline
\end{tabular}

Today, managed Norway spruce stands are the most common land use in Northern Europe. Climate conditions and the dominance of private forest owners organized into large forest associations have favoured the reliance of industry on Norway spruce. For example in 20ı8, a globally leading pulp manufacturer in south Sweden harvested 8.7 million $\mathrm{m}^{3}$ of wood (of which $57 \%$ was used to produce pulp and paper, $32 \%$ as saw logs, II\% for biofuels).

In 2017 the total wood harvest for Sweden was 67 million $\mathrm{m}^{3}$ and a further 6.3 million $\mathrm{m}^{3}$ was imported; of this 37 million $\mathrm{m}^{3}$ was used to produce sawn timber and plywood, 36 million $\mathrm{m}^{3}$ for pulp, paper and cellulose chips (SI 20I8). The annual pulp production was I2 million tons, of which Io million was paper. The pulp mills also produced 600 TWh of energy. Of the wood products $80 \%$ are exported (export value: I45 billion SEK in 20I8).

Forestry contributes with I\% to the national GDP, providing jobs for 6,000 people. However, another 60,000 people are employed in the wood processing industry (YF 20I4). Altogether, with sub-contractors and related professions (transport, IT, education, etc.), the forest sector provides 200,000 jobs and contributes $3 \%$ to national GDP.

The export of construction timber and the local energy supply will offer future business opportunities for wood processing industries. Additional potentials can be seen in the production and export of textiles made from wood, that may replace cotton produced in climate regions with expected water shortages. The challenges in Sweden would be to advance technology and forest policy: so far, only broadleaves produce the long fibers needed for high-quality textiles.

The clearfelling system has prevailed for more than 50 years in Sweden. Natural regeneration is applied occasionally, direct seeding is not common in south Sweden. A typical example of establishing spruce is by planting seedlings in spring, after clearcutting 2 or
4 ha and subsequent soil preparation in the previous autumn. Soil preparation can be done by disc-trenching with a scarifier mounted on a forwarder. Usually, I-2-year-old container seedlings are planted manually at $2 \mathrm{~m}$ spacing in rows of exposed mineral soil. Occasionally, bare-root seedlings are also used in south Sweden. Although there is a well-established breeding programme, with nurseries and established orchards, there is still a need to import Norway spruce seed from north-eastern Europe. On average, the costs of planting including soil preparation are less than I,500 euros ha ${ }^{-1}$. Fencing is not needed for spruce, while other tree species (including Scots pine) are often browsed by moose (Alces alces).

Usually, a pre-commercial thinning is done at 5-6 $\mathrm{m}$ stand height to promote the desired tree species and future stand stability. Later, the stand is thinned approximately three times before harvest (Agestam 2015).

In contrast with many plantations worldwide, the spruce plantations of Scandinavia are mainly of a single native species (Norway spruce). This is similar in La forêt des Landes in France where native maritime pine (Pinus pinaster) is grown as the dominant plantation species. So far Norway spruce in Sweden has proved relatively resistant to diseases, profitable from an owner perspective, and provides the potential for Sweden to transform from a fossil fuel-based economy to the envisaged bioeconomy. Typical for plantations, there is an impressive negative $\mathrm{CO}_{2}$ footprint with $\mathrm{C}$ being sequestered both in the increase of spruce growing stock and the storage of $\mathrm{C}$ in wood material, especially when used to substitute for other construction materials. Sweden's total 2016 greenhouse gas emissions in $\mathrm{CO}_{2}$ eq. were only 9 million tons when LULUCF was included but rise to about 53 million tons when LULUCF is excluded (NFAPS 20I9).

However, the cultivation of Norway spruce on $40 \%$ of the forest area increases the risks of natural 
hazards and lacks social acceptance in some municipalities. For example, insect attacks may increase with climate change (Björkman et al. 20I5). The risk of storm damage is likely to increase due to higher standing volume and more extreme weather events, but can be mitigated by larger spacing between seedlings, earlier thinning and shorter rotation (Subramanian et al. 2016). Also, mixed tree species plantations are considered to be more resilient, especially if admixtures occur naturally in the plantation. As climate change may occur too rapidly for adaptation to be achieved naturally, planting would be an important option in replacing non-suitable tree species faster than natural regeneration processes (Brang et al. 20I4).

The Swedish example suggests that there are regions with an upper limit to the size of area in which the use of mono-species plantations is acceptable, both biologically and for society. Over and above this, the example shows that using an ecosystem-based approach with tree species diversity at a landscape level and combining segregated and integrated forest planning approaches has considerable advantages for commercial, risk management and ecosystem service objectives. Intensive plantations should be avoided in recreational areas, excluded from sensitive areas for nature conservation, and better aligned with corridors to maintain different levels of biodiversity. This approach would address past concerns and conflicts over land use change which have sometimes accompanied afforestation programmes.

\section{References}

Agestam, E. 2015. Gallring. Skogsskötselserien nr 7. Skogsstyrelsen. Jönköping.

Björkman, C., Bylund, H., Nilsson, U., Nordlander, G. and Schroeder, L.M. 20I5. Forest Management to mitigate insect damage in a changing climate: possibilities and uncertainties. In Climate
Change and Insect Pests. Björkman, C. and Niemelä, P. (eds). CABI, pp. 248-266. https://doi. org/10.1079/978I780643786.0248

Brang P., Spathelf P., Larsen J.B., Bauhus J., Boncina A., Chauvin C., Drössler L., Garcia-Guemes C., Heiri C., Kerr G., Lexer M.J., Mason B., Mohren F., Mühlethaler U., Nocentini S. and Svoboda M. 20I4. Suitability of close-to-nature silviculture for adapting temperate European forests to climate change. Forestry 87: 492-503, https://doi. org/ıo.Io93/forestry/cpuoi8

Drössler, L. 20IO. Tree species mixtures - a common feature of southern Swedish forests. Forestry. 83: 433-44I. https://doi.org/Io.Io93/forestry/cpq025

Lindblad M. and Foster D.R. 20I0. Dynamics of long-lived foundation species: the history of Quercus in southern Scandinavia. Journal of Ecology 98, I330-I345. https://doi.org/ıO.IIII/j.I3652745.2010.0I733.x

NFAPS 20I9. National Forestry accounting plan for Sweden. Ministry for the Environment and Energy. Available at: https:/www.regeringen.se/495799/ contentassets/38eaf6f23f284fboa440bo742fe 7 bcf7/national-forestry-accounting-plan-for-sweden. pdf

SKS i984. Gallringsmallar. Södra and Norra Sverige. Skogsstyrelsen, Jönköping.

SI 20I8. Skogsindustrins virkesförsörjning 2017. Skogsindustrierna, Stockholm. https://www.skogsindustrierna.se/skogsindustrin/branschstatistik/ skogsindustrins-virkesforsorjning/

Subramanian N., Bergh J., Johansson U. and Nilsson, U. 20I6. Adaptation of forest management regimes in southern Sweden to increased risks associated. Forests 7: 8. https://doi.org/I0.3390/ f7010008

YF 20I4: Swedish statistical yearbook of forestry. Skogsstyrelsen, Jönköping. https://www.skogsstyrelsen.se/globalassets/statistik/historisk-statistik/ skogsstatistisk-arsbok-20IO-20I4/skogsstatistisk-arsbok-20I4.pdf 
Italy

(see also poplar study in Figure I and Table I)

Italy has II million ha of forest, an area representing around one third of the national land area. At present, the Italian forestry and wood industry sectors generate about $2 \%$ of GDP and provide 450,000 jobs. In the last century forest plantations had been established in mountain and hilly areas for slope protection and/or timber production using mainly conifers such as European larch (Larix decidua) and Norway spruce (Picea abies) in the Alps and black pine (Pinus nigra) in the Prealps and Apennines. Plantations of fast-growing species such as eucalypts, radiata pine (Pinus radiata) and Aleppo pine (Pinus halepensis) were established in south Italy to provide wood for local industries.

The total area of forest plantations is estimated at 639,000 hectares, but currently the majority of these stands are subjected to natural regeneration and a low management regime. Many plantations established with exotic species (e.g. eucalypts and radiata pine) are now returning to natural species mixtures, given that the pulp and paper industries that were supposed to use the products of these stands have disappeared. Reforestation activities are targeted mainly in urban and sub-urban areas where the promotion of ecological value is important. At the present most of Italy's forests are underexploited as less than $40 \%$ of the annual increment is harvested (Cesaro et al. 20I7). Natural and recreational values are being particularly promoted by national and local authorities, even though the recent forest law (Legislative Decree No 34/2018 - Consolidated Law Concerning Forests and Forest Chains) encourages sustainable wood harvesting. In 2018 Italy consumed just over $\mathrm{I} 6$ million $\mathrm{m}^{3}$ of roundwood (FAOSTAT). Of this, $79 \%$ was based on domestic production and $2 \mathrm{I} \%$ on imports. Of the domestic production, about 40\% comes from poplar plantations.

Poplars are grown in short rotation forestry plantations (Figure 7), which are frequent in floodplains and agricultural areas of the Po Valley (northern Italy). Currently, these plantations cover approximately 46,000 ha (Puletti et al. 2018) distributed in about Io,००० farms, with an average area of 4.6 ha per farm.

Despite their prevailing small size, poplar plantations provide valuable timber to the plywood industry as well as small wood for the paper and board industry. Poplar plantations are established with selected hybrid clones which achieve Mean Annual Increment of $\mathrm{I} 7-20 \mathrm{~m}^{3} \mathrm{ha}^{-\mathrm{I}}$, with a maximum of about $30 \mathrm{~m}^{3}$ ha-1, in IO-I2 year cycles. One or two-year old poplar saplings with a height of 3-6 $\mathrm{m}$ and without root systems are planted in ploughed, harrowed and fertilized soil at a density of 280-330 trees per ha. During

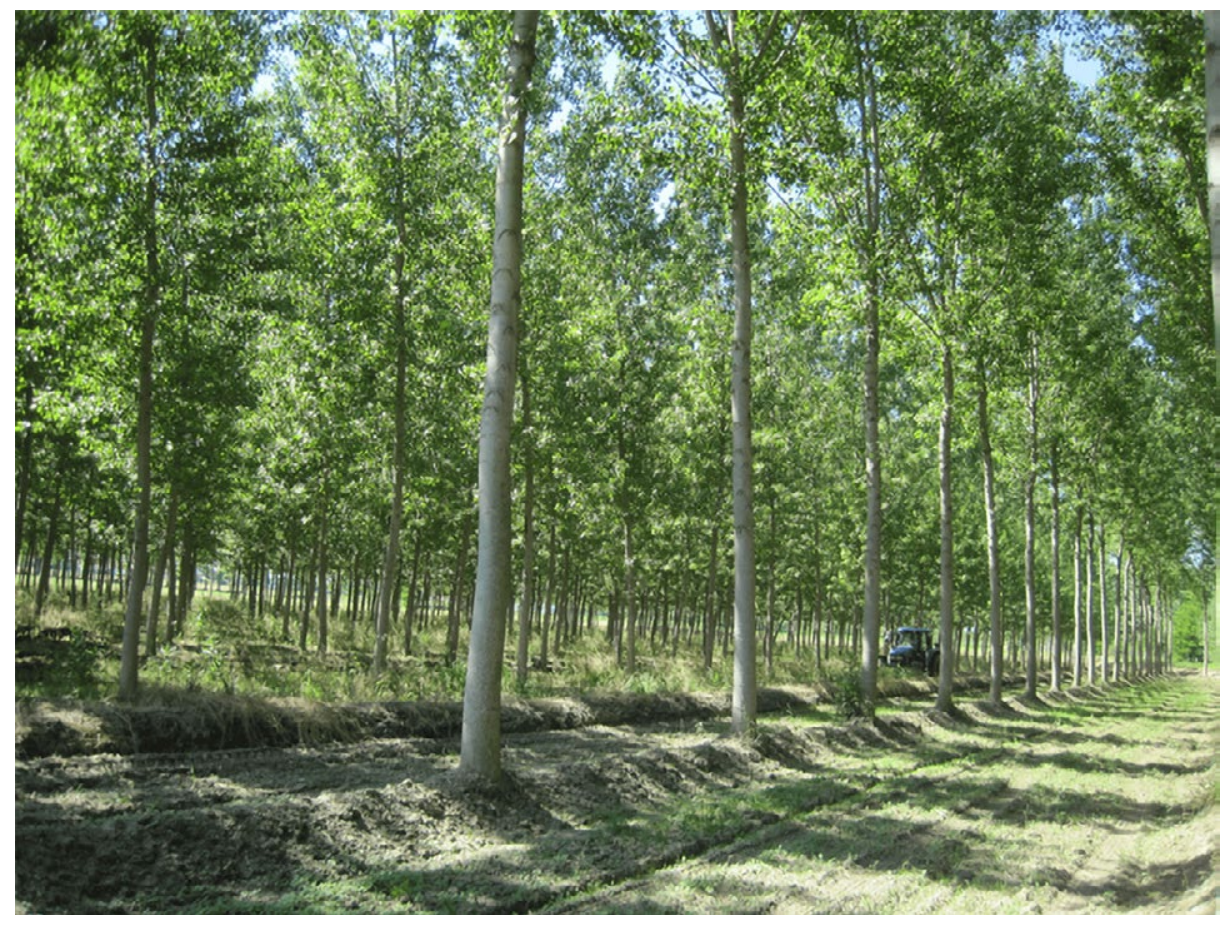

Figure 7. Mature plants in a poplar stand in the Po Valley (Italy). Photo by Gianfranco Minotta. 
the first $4-5$ years after planting, these stands are subject to mechanical weeding and trees are gradually pruned to obtain a straight trunk free from branches to a height of 6-7 $\mathrm{m}$ meters. Insecticide and fungicide treatments may be applied during the rotation depending on the threat and the susceptibility/resistance of the planted clones. In some cases plantations are irrigated to induce a faster tree growth, thus reducing the length of the rotation.

Poplar plantations are usually profitable for farmers, but the level of profitability depends greatly on the market price of poplar timber, which has been subject to considerable variations over the years. These plantations are subsidized by regional governments through the Rural Development Programmes implemented by the EU. At present, public contributions are paid only for polyclonal plantations established with a given percentage of genotypes resistant to the principal poplar pests and diseases.

Recently, forest certification standard schemes have been defined for poplar by the National Association of Poplar Growers in agreement with the regional authorities, and in cooperation with research institutions. At the end of $2018,4,555$ ha and I,932 ha have been certified by PEFC and FSC respectively; certification can help to improve the social perception of poplar cultivation, as well its environmental role. On the other hand, many researchers have demonstrated that the ecological value of poplar stands is higher than that of agricultural crops in terms of soil quality, stand biodiversity and carbon sequestration (Chiarabaglio et al. 20I4). The absorption of GHG in poplar stands is high; in an average year of the full rotation, it ranges from $\mathrm{I} 3$ to I9 $\mathrm{t} \mathrm{CO}_{2}$ ha $^{-\mathrm{T}} \mathrm{yr}^{-\mathrm{I}}$ depending on stand yield and cultivation inputs (Seufert 20I0).

In the rural areas of northern Italy poplar plantations can now perform a number of valuable functions. First, they provide a supply of raw material for the wood industry, which is important to the local economy and in providing employment. Currently, in north Italy there are I3 plywood producers together with II particleboard, 2 MDF and I OSB (oriented strand board) factories which process the timber/wood provided by poplar plantations. At the same time, these plantations contribute to the diversification of farm production and to increasing the ecological quality of the rural environment. Furthermore, the demand for poplar wood of national origin is expected to increase in future, due to the reduction in imports and the possible novel uses of this raw material in the bioeconomy (i.e. biofuel industry). For these plantations to be sustainable it is important to follow cultural practices which minimize the impact of poplar cultivation on the environment, especially in sensitive areas for nature conservation (i.e. Natura 2000 protected areas), thus preventing strong land use conflicts and debates. The application of alternative poplar growing models, such as polycyclic plantations (Facciotto et al. 20I5) and agroforestry alley-cropping systems could be encouraged in future.

\section{References}

Cesaro L., Romano R. and Maluccio S. (editors). 2017. Forestry in Italy: State of health and management, a challenge for the future. European Agricultural fund for Rural Development, National Rural Network, Ministry of Agricultural Food and Forestry policies, Rome.

Chiarabaglio P.M., Giorcelli A. and Allegro G. 2014. Environmental sustainability of poplar stands. In: 'Actas de las Jornadas de Salicaceas 20I4' Cuarto Congreso Internacional de Salicáceas en Argentina "Sauces y Álamos para el desarrollo regional" Ciudad de La Plata, Buenos Aires, Argentina, March I8-2I, 20I4. ISSN i850-3543: 8 pp.

Facciotto G., Minotta G., Paris P. and Pelleri F. 2015. Tree farming, agroforestry and the new green revolution, a necessary alliance. Proceedings of the Second International Congress of Silviculture. Florence, November 26-29 20I4, Vol.II: 658-669.

Puletti N., Coaloa D., Chiarabaglio P.M., Rosso L., Fattorini L., Marcelli A., Mattioli W., Grotti M., Quatrini V., Castaldi C., Turco R., Bernardini V., Tomaiuolo M., Sciré M. and Corona P. 20I8. Inventario degli impianti di arboricoltura da legno in Italia (Italian inventory of tree plantations for timber/ wood production). CREA-Centro di ricerca Foreste e Legno, FederlegnoArredo, Arezzo-Rome (Italy).

Seufert G. 20Io. Il "Kyoto Experiment" del CCR di Ispra: La Pioppicoltura come sequestratore di carbonio (The "Kyoto Experiment" carried out at the Ispra CCR: the contribution of poplar growing to carbon sequestration). Presentation held at the VIIth Edition of Vegetalia Agroenergie, March, I92I 20IO, Cremona (Italy). 


\section{Georgia}

(see also Scots pine study in Figure I and Table I)

Georgia has 3.7 million inhabitants and 2.8 million ha of forests, which cover $40 \%$ of its area and are state-owned. The mountain forests fulfill protective functions to prevent erosion, floods or landslides. Georgia is listed with two global biodiversity hotspots (Olson and Dinerstein 1998). The country committed to expand the national protected areas from 0.5 to I. 3 million ha and to include at least I million ha of forest (UNECE 20I8). The contribution of forestry to the GDP was $0.3 \%$ in 2014 , excluding illegal logging and processing of illegally cut wood (Garforth et al. 20I4).

In managed forests, the prevailing harvest regime is selective felling. Remaining stands have a large potential to regenerate naturally, even though forests have been illegally harvested and overexploited during the last three decades. According to the National Forest Concept, managed forests should be used for multiple purposes, especially for firewood supply, drinking water, timber, non-timber products and to prevent erosion and floods. Only 72,000 ha have been reported as planted forest. The main goal at the time of planting was to stop erosion, therefore, mostly Sosnowskyi/Scots pine (Pinus silvestris) was planted in the last century. Corsican pine (Pinus nigra), eucalypt and black locust were introduced in some areas.
In 2003, Georgia started to plant forest again and 400 ha of new forest have been documented from 2003-2017. These are established mostly by the National Forest Agency with state budget. Additionally, 250 ha of various tree species have been planted in urban areas, and 32 ha of black locust plantations for short rotation coppice to produce poles for vineyards and firewood. Most of the planted stands have been established after wildfire in the mountains where local origin native pine (estimated mean annual increment $>5 \mathrm{~m}^{3} \mathrm{ha}^{-\mathrm{I}}$ ) and other pioneer species were planted to prevent erosion and promote forest succession. Acer species were planted in mixture with pine as fire barriers. About Ioo ha were financed by foreign development aid, but most of these areas burnt down again. The prevailing forest function in this tourist area is recreation.

The planting density in Borjomi is 3,500 pine seedlings ha ${ }^{-1}$. Local temporary nurseries supply autochthonous plant material. Early vegetation management and cleaning is supervised by the forest agency.

The function of new forests is usually provided in the description of planting projects. So far, "recreation" and "plantation for wood production" have been used in management records. Sometimes, the forest function is more specifically addressed (e.g. firewood, saw logs, carbon sequestration, nature protection, etc.). In some other areas, broadleaf tree

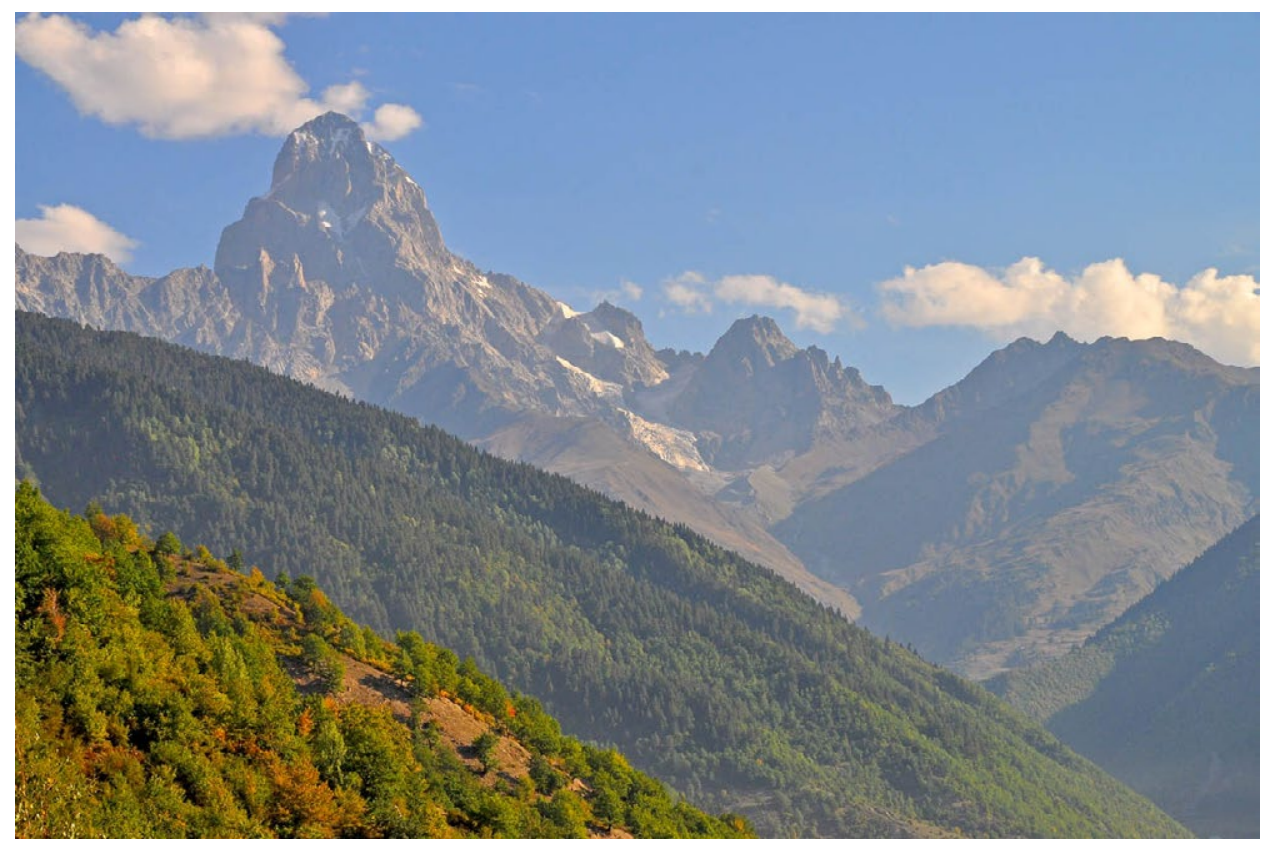

Figure 8. Typical landscape of the Caucasus with alpine meadows, mountain pastures, and native forests with high tree species diversity. Photo by Lars Droessler. 
species were planted for forest restoration purposes (i.e. oak, birch, poplar, etc.).

Illegal cuttings are the largest threat to the forests, of the 2.7 million $\mathrm{m}^{3}$ of wood harvested in 2014, 2 million $\mathrm{m}^{3}$ was illegal harvest (Garforth et al. 20I6). Georgia has over 200 small wood processing companies and sawmills, and a pellet factory was recently established. Secure land tenure is also necessary to increase interest in tree planting. Currently, a new forest code is being prepared to define forest based on the area covered by trees, including tree plantings on private land and by natural succession. Another challenge is to increase awareness of shortages in wood supply and to improve professional education. The national forest strategy set the restoration of degraded forests and reforestation as a main priority. It suggests the use of fuelwood from sustainably managed forests, and also promotes short-rotation plantations for fuel supply.

Georgia commits itself to restore or plant a total area of 9,000 ha of forest by 2030. Currently, I,500 ha are proposed for reforestation and afforestation on the area of the national forest fund, natural regeneration of forests will be promoted on 7,500 ha (NDC 20I7). Additionally, up to 35,000 ha could be planted if funding would be provided (UNECE 20I8). However, this large amount would present a huge challenge for the provision of suitable plant material, professional equipment and training, to choose alternative succession areas, and to monitor the success of forest restoration. Planting activities would be coordinated with measures to assist natural regeneration and introducing sustainable management practices on up to 250,000 ha; an estimated area to restore forest is 200,000 ha (UNECE 20I8). Different forest regions plan their supplies of plant material and manage their own temporary nurseries today, based on the state budget. A large national nursery was built up in recent years, but is not used for forest plantations any more, as logistics to get fresh plant material to the afforestation sites was a problem.

Recent history may cause a shortage of wood supply until naturally regenerated forests can supply wood sustainably again. Especially in rural areas with high demand for firewood near protected areas, plantations could bridge the gap between supply and predicted demands for wood. Fuelwood production by new planted coppice forest could counteract shortages in Io-30 years. Also, pine plantations established to stop erosion some decades ago, are mostly unthinned and could be managed to mitigate wood shortages.

Garforth et al. (2016) concluded that Georgia should invest in its forests as part of its development strategy. New forest plantations could secure local firewood supply and generate income in remote areas of the country. First studies of carbon stock have been initiated with the first national forest inventory. Good progress was made during recent years to describe sustainable forest management by national criteria and indicators that have been developed with UNECE and FAO. However, administrative and managerial capacity at the operational level have to be developed. After 2020, the results of the first national forest inventory are expected to be available. With the information about wood resources and with robust growth estimates, future harvest levels can be determined and periods of wood shortage identified. Meanwhile, the identification of site-adapted tree species, and pioneering plantation activities accompanied by long-term experiments to study forest growth and carbon sequestration should be a joint task for the forest sector and research.

\section{References}

Garforth M., Nilsson S. and Torchinava P. 20I6. Integrated Biodiversity Management South Caucasus: Wood Market Study. GIZ, Tbilisi.

NDC 20I7. Georgia's intended nationally determined contribution submission to the UNFCCC. Ministry of Environment and Natural Resources Protection of Georgia, Tbilisi, 20I7. https://www4.unfcc.int/sites/ndcstaging/PublishedDocuments/ Georgia\%2oFirst/INDC_of_Georgia.pdf

Olson D. M. and Dinerstein E. I998. The Global 200: A representation approach to conserving the Earth's most biologically valuable ecoregions. Conservation Biol. I2:502-515. https://doi. org/I0.1046/j.I523-I739.I998.012003502.x

UNECE 20I8. Forest Landscape Restoration in the Caucasus and Central Asia. Economic Commission for Europe, Committee on Forests and the Forest Industry, Seventy-sixth session, Vancouver, Canada, 5-9 November 20I8. Note by the Secretariat. URL: https://www.unece.org/fileadmin/DAM/timber/meetings/2018/20181105/ ECE_TIM_20I8_Inf._3_Forest_Landscape_Restoration.pdf 


\section{Appendix 1. Definition of plantation forests used in this study}

Here we define plantation forests as "Forests predominantly composed of trees established through planting and/or deliberate seeding and which are being actively managed for provisioning services, climate regulation or both. Forests established only by natural regeneration, planted forests that are left unmanaged, and forests that are managed mainly for purposes other than provisioning services and climate regulation are not considered plantation forests".

The definition of plantation forests we propose here is based on the definition of plantation forest adopted by FAO in its ongoing Global Forest Resource Assessment, which we apply to the European context. We are interested in the potential of plantation forests (forests made up of mainly plantations) rather than plantations alone because of the importance of scale and diversity and we focus mainly on wood production and climate regulation. We feel that the definition of plantation forests that we have adopted and the new FAO definition of plantation forest are useful because they incorporate a requirement for both creation mainly by planting or deliberate seeding (Table AI) and for active management (Figure AI).

The definition adopted for this report includes forests created by afforestation, reforestation, forest restocking and forest restoration as long as they are then actively managed mainly to provide wood resources or for climate regulation along with other ecosystem services. In Europe, forest plantations are sometimes of single species and of even-age and are often of selected or improved plant material, but they may involve a number of tree species (mixed), trees of different ages (uneven-aged) and be of irregular planting pattern.

For this definition to be useful it is necessary to define active management. We base this on the forest management approaches (FMAs) proposed in Duncker et al. (2012) and the forest management strategies presented in Nabuurs et al. 20I9. We take active management to mean forests that are in the very intensive management, intensive management and the more actively managed forests within the multifunctional management categories mapped by Nabuurs et al. 2019 (see Figure A1). The more active management category can be characterized by the use of site preparation (e.g. stump extraction, ploughing), fertilization, cleaning and thinning, possibly pruning, and final harvesting by mostly clear-cut, strip-cut and clear-cut with some retention trees. The inclusion of the more actively managed forests category means that significant areas of Northern Europe mixed forests (although often with many stands dominated by a single species) are included here. This means that 'example C' of Dunker et al. (20I2) which is Norway spruce (70\%) growing in the county of Västerbotten, Sweden is included, as is 'example D' which is forests of predominantly Sitka spruce managed in Scotland and forests of similar levels of management. The forests classified by Nabuurs et al. (2019) as low-intensity management, close-to-nature management and strict nature management are excluded.

Our definition excludes the extensive areas of semi-natural and natural woodland in Europe which may have been planted but which now have little or no management. Because they were planted these areas were categorized as planted forests in pre2020 FAO Global Forest Resource Assessments. Our definition is wider than the new FAO definition of plantations (we include planted, managed forests including those of uneven age, irregular spacing and with more than two species), and wider than the State of Forests in Europe definition ${ }^{\mathrm{T}}$ which does not include the more actively managed multifunctional management areas that we have included.

\section{References}

Duncker P.S., Barreiro S.M., Hengeveld G.M., Lind T., Mason W.L., Ambrozy S. and Spiecker H. $20 \mathrm{I2}$. Classification of Forest Management Approaches: A New Conceptual Framework and Its Applicability to European Forestry. Ecology and Society I7(4): 5I. http://dx.doi.org/I0.575I/ES-05262-I7045I Nabuurs G-J., Verweij P., Van Eupen M., Perez-Soba M., Pulzl H. and Hendriks K. 20I9. Next-generation information to support a sustainable course for European forests. Nature Sustainability https:// doi.org/I0.1038/s41893-019-0374-3

I Forest Europe, 20I5: State of Europe's Forests 20I5 https://foresteurope.org/state-europes-forests-20I5-report/ 
Table A 1 . The areas of planted forests in Europe (thousands of hectares) by country. Except where the footnote provides other sources these areas are the sum of the planted forest areas and coppice areas as defined by the UNECE 2010 (http://www.unece.org/forests/fpm/onlinedata.html).

\begin{tabular}{|c|c|c|c|}
\hline & 2010 & & 2010 \\
\hline Albania & 94 & Liechtenstein & 0.3 \\
\hline Andorra' & ○ & Lithuania & 536 \\
\hline Austria & 1781.1 & Luxembourg & 28.3 \\
\hline Belarus & 2146.4 & Malta & 0.35 \\
\hline Belgium & 397.7 & Monaco $^{2}$ & 0 \\
\hline Bosnia and Herzegovina $\% 4$ & 1047.0 & Montenegro & 405.13 \\
\hline Bulgaria & 2542 & Netherlands & 332.61 \\
\hline Croatia & 70 & North Macedonia & 0 \\
\hline Cyprus & 30.42 & Norway & 1463 \\
\hline Czechia & 2647.39 & Poland: & 8877.0 \\
\hline Denmark & 441.52 & Portugal & 865 \\
\hline Estonia & 174.18 & Republic of Moldova* & 2.0 \\
\hline Finland & 6529.2 & Romania & 1433 \\
\hline France & 3765 & Russian Federation & 16990.9 \\
\hline Georgia* & 72.0 & Serbia* & 2532.0 \\
\hline Germany & 5368 & Slovakia & 807 \\
\hline Greece & 140 & Slovenia & 36 \\
\hline Holy See & o & Spain & 2881.55 \\
\hline Hungary & 1736.69 & Sweden & 12563.88 \\
\hline Iceland & 30.82 & Switzerland & 224 \\
\hline Ireland & 654.23 & Turkey & 4260.32 \\
\hline Italy & 621 & Ukraine & 6355 \\
\hline Latvia & 628 & United Kingdom ${ }^{3}$ & 2716 \\
\hline
\end{tabular}

1 Andorra has Pyrenees conifer and mixed forests mostly protection function.

2 Monaco has a total forest area of 202 ha (FAO GFRA National Report)

3 UK data from FC Forest Statistics 2018

42005 data

* Data for planted forests from FAO GFRA National Reports (table 2.4) 


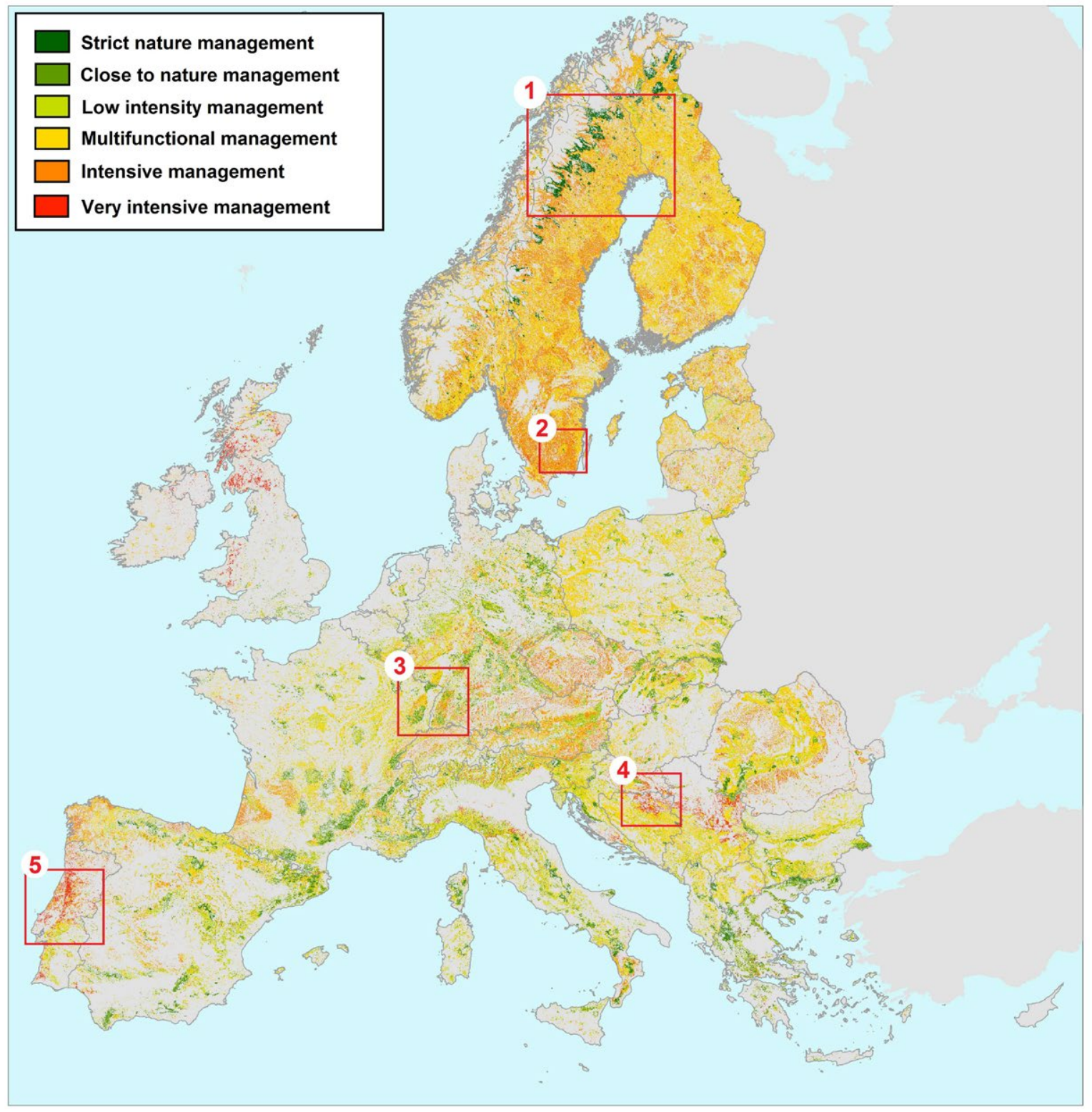

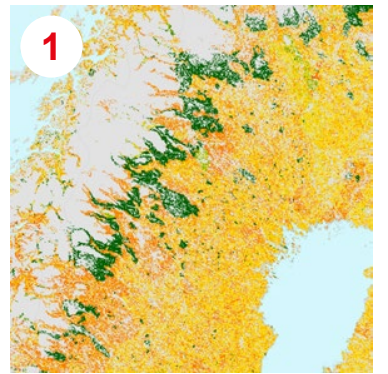
5

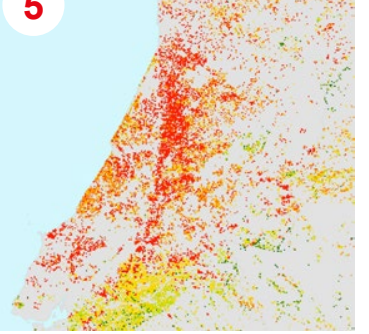

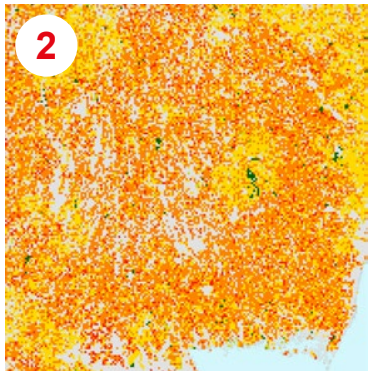
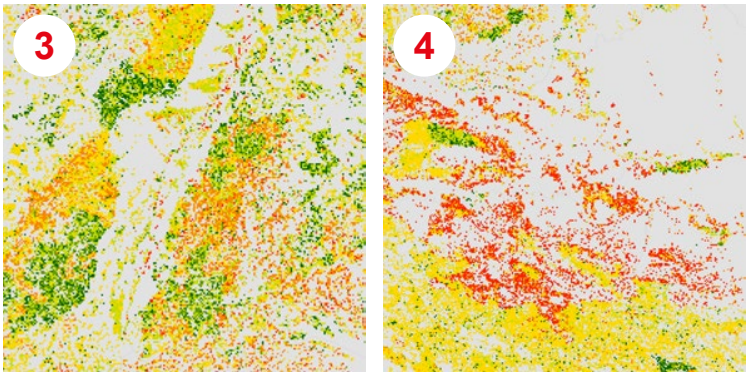

Figure A1. Map from Nabuurs et al. (2019) showing the distribution of forest management strategies in the European Economic Area. The enlarged squares of 1) northern Sweden, 2) southern Sweden, 3) The French Vosges, 4) Croatia, Serbia \& Bosnia Herzegovina and 5) Portugal show how the categories are interwoven patterns in some areas but are more spatially separated elsewhere. The percentages of the total forest area in each management category are as follows: very intensive management $3.5 \%$, intensive management $22.5 \%$, multifunctional management $45 \%$, low-intensity management $15 \%$, close-to-nature management $7 \%$ and strict nature management $7 \%$. 


\section{Appendix 2. Site indicator values for analysis of land use impact.}

The indicator values used to calculate the land use impact scores for vegetation, biodiversity, soil and water as shown in Table I, section 4.2. Impact scores estimate distance from natural state (natural = 0 ; max. impact $=$ IOO). They are proxies for the order (low entropy) of the system (maximum in natural state and o in dead systems). Explanatory notes (II9) are provided and see details of the scoring system in Peters et al. 2003 .

\begin{tabular}{|c|c|c|c|c|c|c|c|}
\hline & Poplar & Spruce & Pine & $\begin{array}{l}\text { Sitka } \\
\text { spruce }\end{array}$ & Oak & $\begin{array}{l}\text { Crop- } \\
\text { land }\end{array}$ & $\begin{array}{l}\text { Explanatory } \\
\text { note }\end{array}$ \\
\hline & Italy & Sweden & Georgia & Ireland & Belgium & Belgium & \\
\hline \multicolumn{8}{|l|}{ 1. Ecosystem structure } \\
\hline \multicolumn{8}{|l|}{1.1 Vegetation structure } \\
\hline 1.1.1 Above-ground biomass & 60 & 40 & 30 & 50 & 10 & 95 & 1 \\
\hline 1.1.2 Leaf Area Index & 50 & 20 & 40 & 40 & 20 & 75 & 2 \\
\hline 1.1.3 Free Net Primary Productivity & 70 & 60 & 40 & 50 & 30 & 80 & 3 \\
\hline Vegetation Impact & 60 & 40 & 37 & 47 & 20 & 83 & 4 \\
\hline \multicolumn{8}{|l|}{1.2 Biodiversity } \\
\hline 1.2.1 Loss of plant species richness & 80 & 50 & 40 & 70 & 20 & 90 & 5 \\
\hline 1.2.2 Non-native canopy cover & 90 & o & o & 70 & o & 95 & 6 \\
\hline 1.2.3 Biocide use & 70 & o & o & 10 & 0 & 90 & 7 \\
\hline 1.2.4 Fertilizer use & 40 & ○ & $\circ$ & 15 & 0 & 80 & 8 \\
\hline 1.2.5 Use of irrigation or drainage & 20 & o & 0 & 30 & 0 & 10 & 9 \\
\hline Biodiversity Impact & 60 & 10 & 8 & 39 & 4 & 73 & 10 \\
\hline \multicolumn{8}{|l|}{ 2. Ecosystem function } \\
\hline \multicolumn{8}{|l|}{2.1 Soil } \\
\hline 2.1.1 Soil work & 15 & 3 & 2 & 8 & 2 & 90 & 11 \\
\hline 2.1.2 Soil erosion & 5 & 1 & o & 2 & 0 & 30 & 12 \\
\hline 2.1.3 Loss of cation exchange capacity & 30 & 20 & 10 & 20 & 10 & 40 & 13 \\
\hline 2.1.4 Loss of base saturation & o & 30 & 10 & 30 & 10 & o & 14 \\
\hline Soil Impact & 13 & 14 & 6 & 15 & 6 & 40 & 15 \\
\hline \multicolumn{8}{|l|}{ 2.2 Water balance } \\
\hline 2.2.1 Loss of evapotranspirative cooling & o & 0 & 10 & o & 10 & 40 & 16 \\
\hline 2.2.2 Loss of soil infiltrability & 20 & 10 & 5 & 15 & 5 & 30 & 17 \\
\hline Water impact & 10 & 5 & 7.5 & 7.5 & 7.5 & 35 & 18 \\
\hline Overall land use impact & 36 & 17 & 14 & 27 & 9 & 58 & 19 \\
\hline
\end{tabular}

Notes on the above scores:

1. Biomass is an essential feature of ecosystem structure, creating microclimate, habitats, etc. Essentially the rotation length determines the average standing biomass.

2. Leaf Area index is related to the height and the layeredness of vegetation, and determines the filtering capacity of the vegetation for light, rain, dust, etc. Tree-based systems have higher LAI. Average LAI of cropland is very reduced if no cover crop is used in winter.

3. FNPP (Free Net Primary Productivity) is the fraction of the total net primary productivity that is not harvested, and that stays in the ecosystem for natural ecosystem processes. It will be typically higher in plantation forests than in croplands, if stumps, harvest residues, pruning residues and leaf litter stay in the forest.

4. Average of the 3 vegetation structure indicators. 
5. Can be done for any taxa, here for plant species. The effect is very context dependent.

6. The idea is that native species have a co-evolved network of specialized associated species. Cover of different layers (tree, shrub, herb) are counted together. In this example both maize and interamerican poplar clones are exotic, and take a large part of the canopy cover. Vegetation management is, however, very limited in poplar plantations, and spontaneous undergrowth develops.

7. Biocides are harmful for the food web. The impact includes the factors $\%$ of the area treated, intensity and frequency of the treatment.

8. Fertilizers disturb the natural plant nutrition, and may lead to eutrophication. The impact includes the factors $\%$ of the area treated, intensity and frequency of the treatment.

9. Changing the natural water conditions may be harmful for the natural system. The impact includes the factors $\%$ of the area treated and intensity of the irrigation/drainage applied. In poplars and maize, drainage is used to decrease water tables.

10. Average of the 5 biodiversity indicators.

11. Ploughing leads to loss of soil organic matter, macropores, etc. The impact includes the factors $\%$ of the area treated, depth and frequency of the intervention.

12. Sediment loss leads to decreased site quality, and causes off-site damages. The more permanent canopy cover and rooting of forests has a larger control over sediment loss than croplands, which may be denuded of vegetation for a good part of the year.

13. CEC (cation exchange capacity) is the storage capacity for exchangeable nutrients, like Ca, K, Mg. CEC is mainly determined by soil texture (more or less invariable for a given site) and soil organic matter.

14. Base saturation is an indicator of soil fertility. Poplars keep soils fertile, and in cropland BS is controlled by fertilization.

15. Average of the 4 soil indicators.

16. The evapotranspiration (ET) level of the natural system is in balance with the water flow in the aquatic system. Slightly increased ET like in poplars or clearly decreased ET like in cropland (because of low LAI during part of the year) both cause impact.

17. Infiltration is important for plant growth and refilling of aquifers. Poplar plantations will have good infiltration rate but lower infiltration due to increased ET. Croplands will have reduced infiltration rates (soil compaction) but increased discharge (which will partly infiltrate and partly runoff superficially).

18. Average of the 2 water indicators.

19. In plantation forest the impact is only half of that in cropland due to less frequent and less intensive interventions, leading to a more close to nature structure and function. 


\section{Glossary}

Agroforestry is the integration of trees with crops, animals or both in order to benefit from the resulting ecological and economic interactions.

Carbon dioxide equivalent or $\mathrm{CO}_{2}$ eq: a common unit for different greenhouse gases where $\mathrm{CO}_{2}$ e signifies the amount of $\mathrm{CO}_{2}$, which would have the equivalent global warming impact.

Disturbance regimes describe the frequencies, sizes and severities of disturbance over extended spatial and temporal scales that are typical for a landscape. They often comprise the interplay of different disturbance agents, such as wind and bark beetles.

Forest vitality is rigorous/strong growth resulting from good tree health, site conditions and silviculture.

Forest disturbances are discrete events that dramatically alter the structure, composition and function of an ecosystem, community or population and change resource availability or the physical environment. Prominent examples in Europe's forests are wildfires, insect outbreaks or windthrow events.

Forest rents (\% of GDP) are roundwood harvest times the product of average prices and a region-specific rental rate.

Harvested Wood Products (HWPs) are wood-based materials harvested from forests, which are used for products. Wood products contribute to mitigating climate change e.g. through forming a storage pool of woodbased carbon.

Life Cycle Assessment (LCA): Method for analyzing and assessing the environmental impacts of a material, product or service throughout its entire life cycle.

Mean Annual Increment (MAI): Is the average growth per year of a stand of trees and is usually expressed in the units $\mathrm{m}^{3}$ of wood volume per hectare $\left(\mathrm{m}^{3} \mathrm{ha}^{-\mathrm{T}}\right)$.

Permanent polycyclic plantations: Forest plantations of mixed species where there are several groups of main trees with different objectives and lengths of productive cycles.

Platform chemicals are building blocks which can be converted to a wide range of chemicals or materials.

Salvage logging is the practice of harvesting dead, dying, damaged, or weakened trees to recover economic losses from natural disturbances.

Sanitation logging is the harvesting of trees for the purpose of removing insects or disease.

Planted forest * Forest predominantly composed of trees established through planting and/or deliberate seeding. Explanatory notes

I. In this context, predominantly means that the planted/seeded trees are expected to constitute more than 50 percent of the growing stock at maturity.

2. Includes coppice from trees that were originally planted or seeded. 
Plantation forest * For the definition of planted forests used in this report please see Appendix I. The FAO definition is Planted Forest that is intensively managed and meet ALL the following criteria at planting and stand maturity: one or two species, even age class, and regular spacing

Explanatory notes

I. Specifically includes: short rotation plantation for wood, fibre and energy.

2. Specifically excludes: forest planted for protection or ecosystem restoration.

3. Specifically excludes: Forest established through planting or seeding which at stand maturity resembles or will resemble naturally regenerating forest.

Afforestation * Establishment of forest through planting and/or deliberate seeding on land that, until then, was under a different land use, implies a transformation of land use form non-forest to forest.

Deforestation * The conversion of forest to other land use independently whether human-induced or not.

Reforestation * Re-establishment of forest through planting and/or deliberate seeding on land classified as forest.

Native tree species * A tree species occurring within its natural range (past or present) and dispersal potential (i.e. within the range it occupies naturally or could occupy without direct or indirect introduction or care by humans).

Introduced tree species * A tree species occurring outside its natural range (past or present) and dispersal potential (i.e. outside the range it occupies naturally or could occupy without direct or indirect introduction or care by humans).

Sustainable forest management * A dynamic and evolving concept [that] is intended to maintain and enhance the economic, social and environmental value of all types of forests, for the benefit of present and future generations.

*These definitions are unaltered from FAO 2018 Global Forest resources Assessment 2020 Terms and Definitions. FAO Forest Resources Assessment working paper i88. 

X e are living in a time of accelerated changes and unprecedented global challenges: energy security, natural resource scarcity, biodiversity loss, fossil-resource dependence and climate change. Yet the challenges also demand new solutions and offer new opportunities. The cross-cutting nature of forests and the forest-based sector provides a strong basis to address these interconnected societal challenges, while supporting the development of a European circular bioeconomy.

The European Forest Institute is an unbiased, science-based international organisation that provides the best forest science knowledge and information for better informed policy making. EFI provides support for decision-takers, policy makers and institutions, bringing together cross-boundary scientific knowledge and expertise to strengthen science-policy dialogue.

This work and publication has been financed by EFI's MultiDonor Trust Fund for policy support, which is supported by the Governments of Austria, Czech Republic, Finland, Germany, Ireland, Italy, Lithuania, Norway, Spain and Sweden.

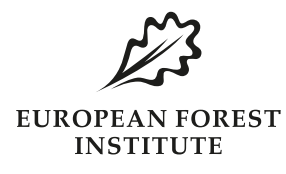

www.efi.int 